\title{
تأثير خصائص الثك المهني للمدقق على جودة التدقيق
}

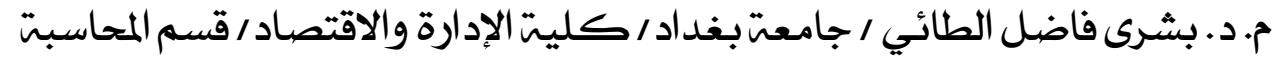

الباحث/ علاء الدين عبد الرحمن عثمان اجمان بغداد

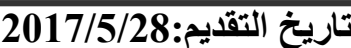

تاريخ القبول:2017/8/28

|lim:

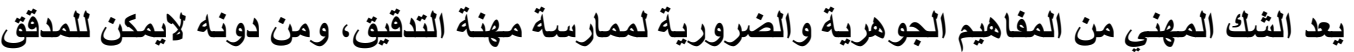

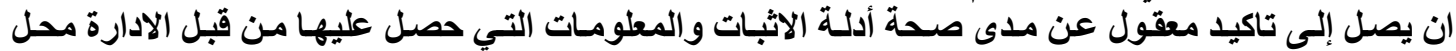

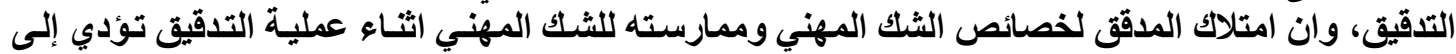

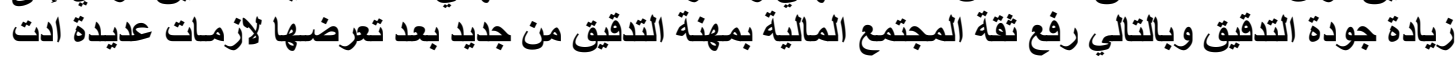

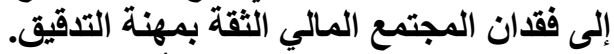

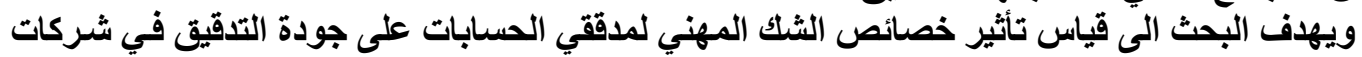

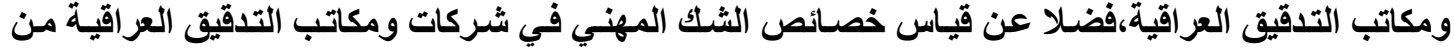

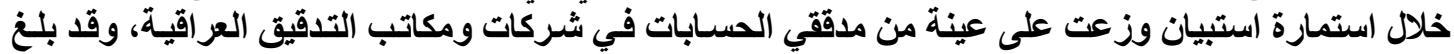

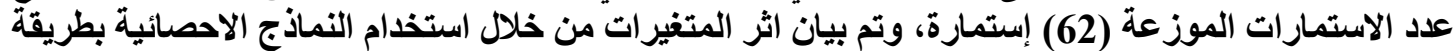

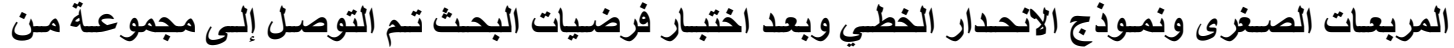

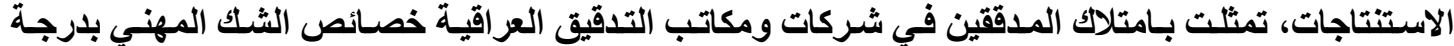

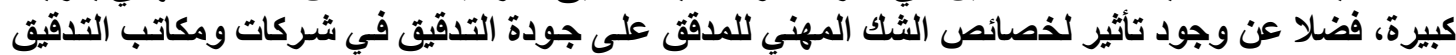

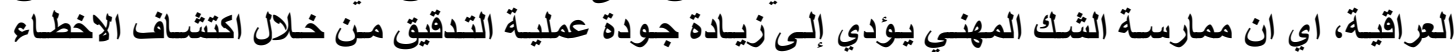

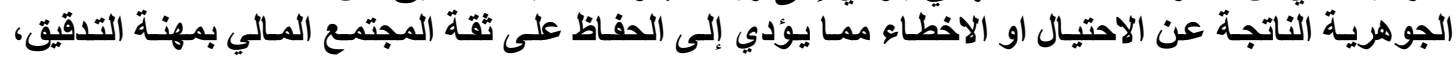

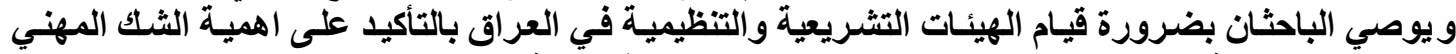

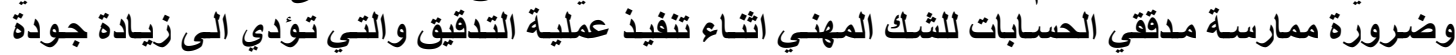
التققيق. المطاحمات الرئيسة لابحث/ الثك المهني، خصائص الثك المهني، جودة التدقيق.

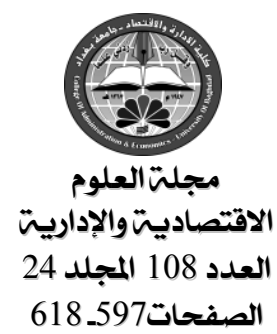


يعد الثكك المهني من المفاهيم الجوهرية والضرورية لممارسة مهنة التدقيق، ومن دونه لايمكن للمدقق

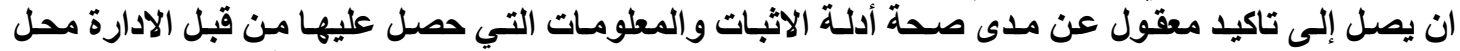

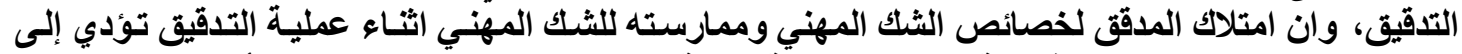

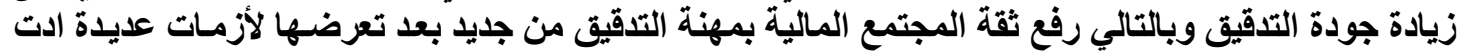

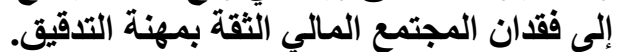

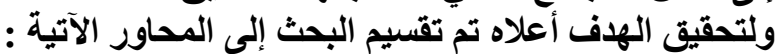

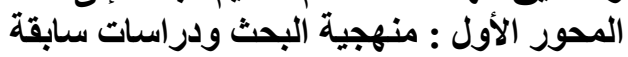

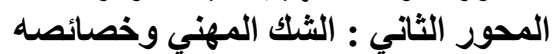

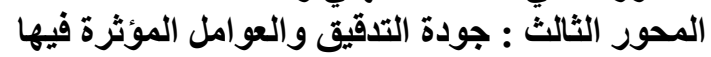

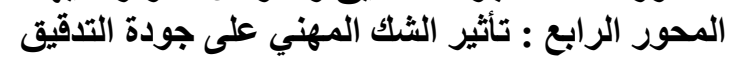

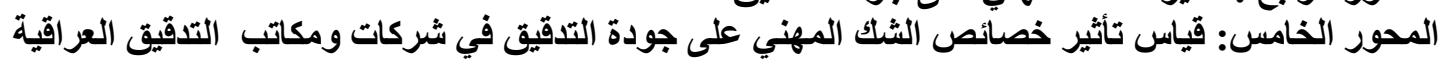
المحور السادس: الإستتناجات والتوصيات

\section{الحمور الأول/ منهجية البحث ودراسات سابقة}

اولاا: هشكلة البحث : وتتمثل مشكلة البحث في التساؤلات الاتية:

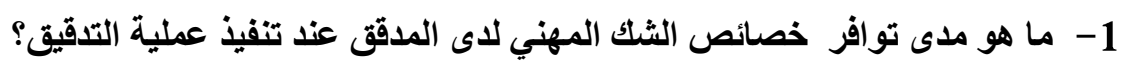

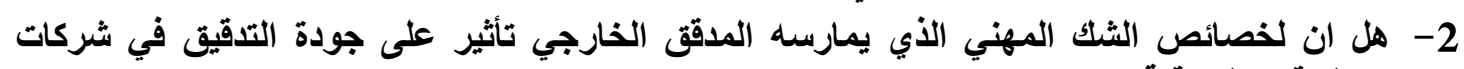
ومكاتب التدقيق العراقية لفصان؟

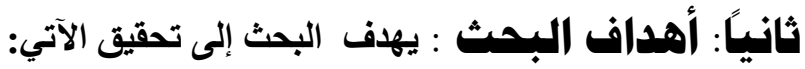

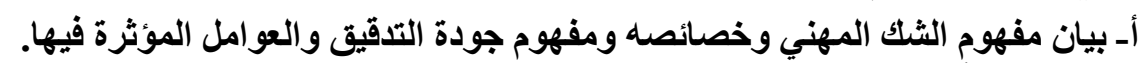

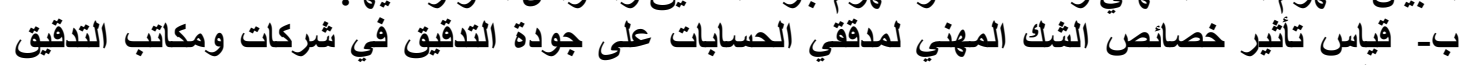
العراقية.

ثالثًا: فرضية البهث: يستند البحث إلى الفرضية الآتية:

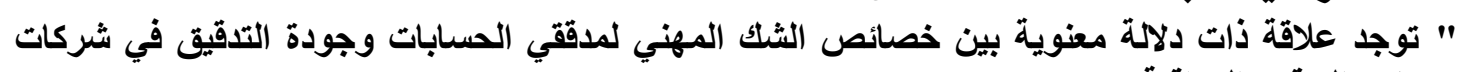
ومكاتب التتقيق العراقية".

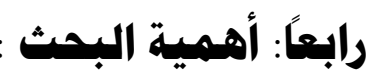

تتمثل أهمية البحث في جانبين، اذ يمثل الجانب الاول الجانب النظري الذي يوضح التبح الهمية ممارسة

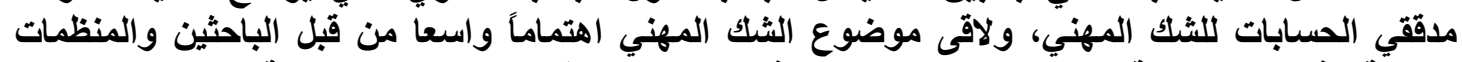

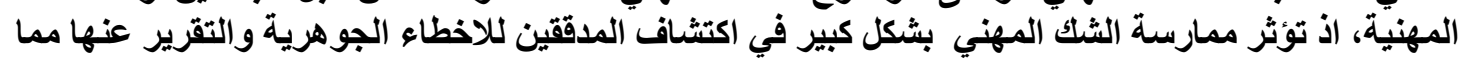

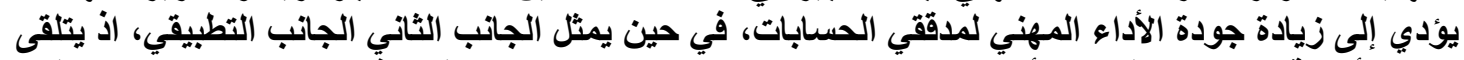

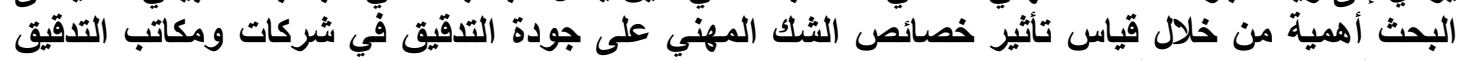

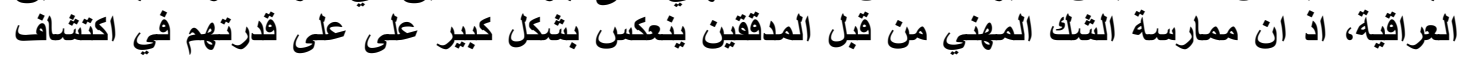
الاخطاء و التلاعبات مما يعزز من جودة التدقيق. 


\section{تأثير خمائس الشلك المهني للمدقق علمى جودة التدقيقا}

\section{خاهساً: دراسات سابقة}

1- دراسة (الصباغ وشرف،2014) بعنوان " مدى اهتمام الابحاث الاكاديمية والمعايير المهنية بممارسة

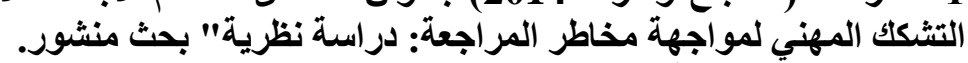

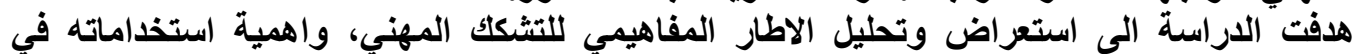

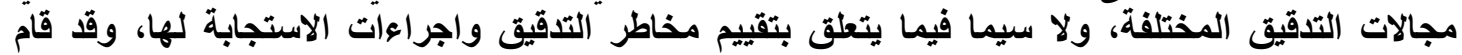

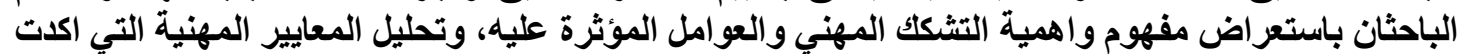

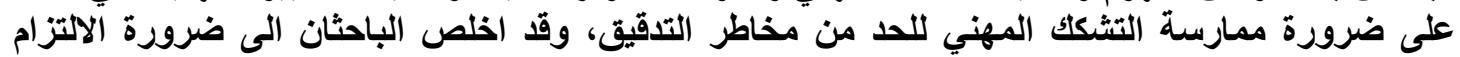

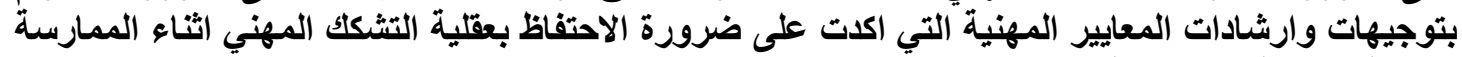

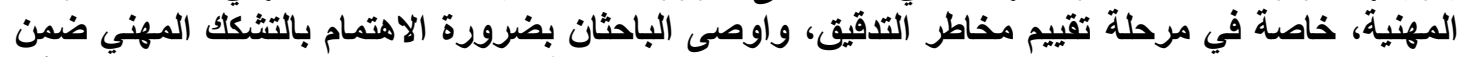

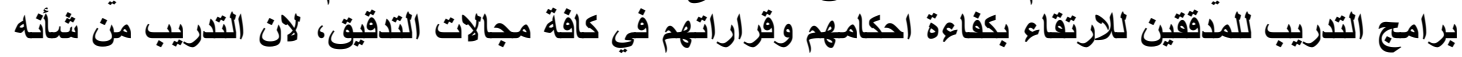

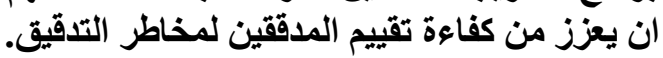

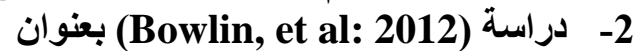

"The Effects of Auditor Rotation, Professional Skepticism, and Interactions with Managers on Audit Quality"

"أثر تدوير المدقق، الثك المهني، والتفاعل مع المدراء على جودة التدقيق" بحث منشور.

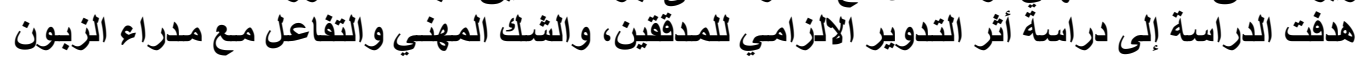

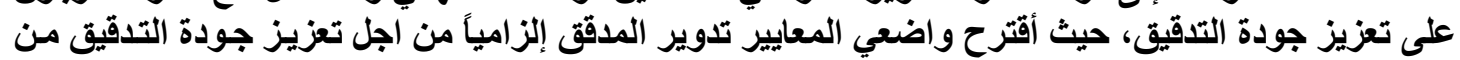

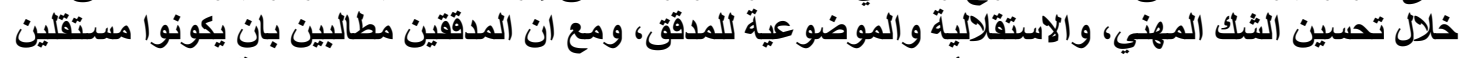

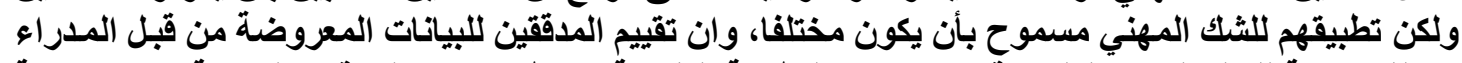

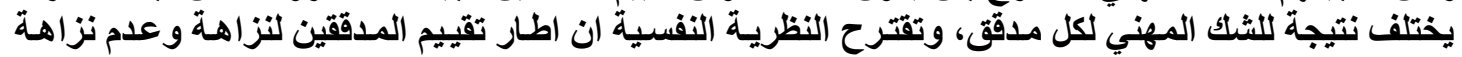

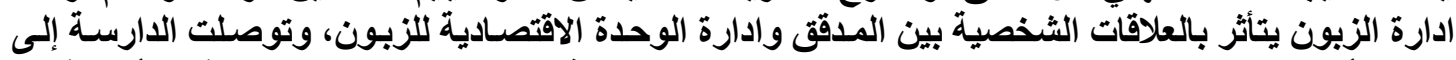

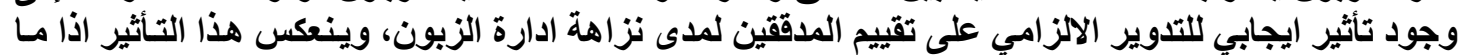
امتلك المدقي عقلية متشككة.

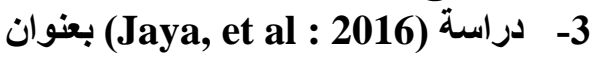

Skepticism, Time limitation of audit, Ethics of professional accountant and audit quality

"الثك، الوقت المحدد لعملية التدقيق، الاخلاق المهنية للمحاسبين وجودة التدقيق " بحث منشور.

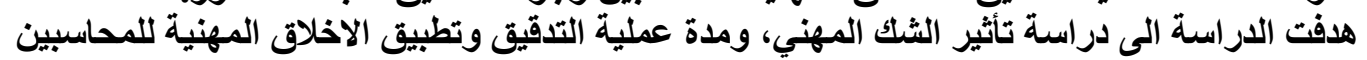

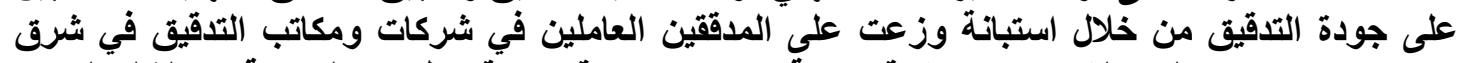

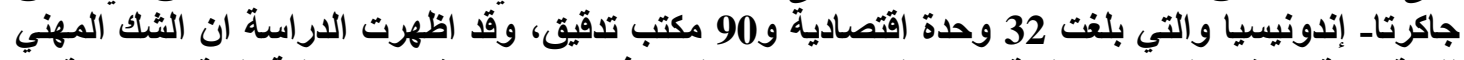

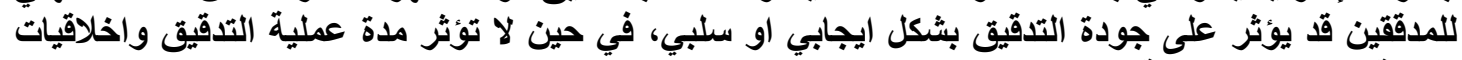
المهنة على جودة عملية التدقيق بشكل كبير.

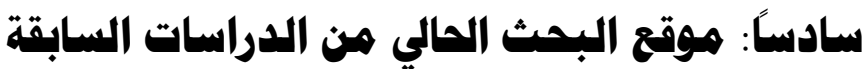

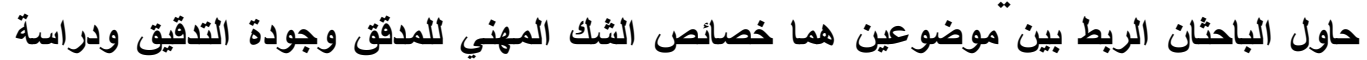

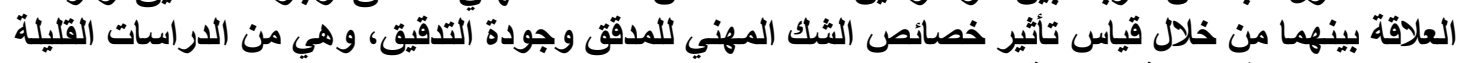
التي تم تناولها في البيئة العراقية. 


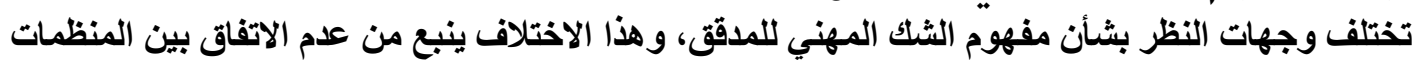

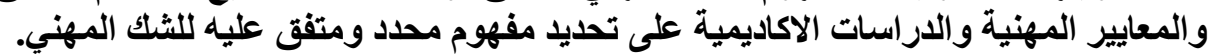

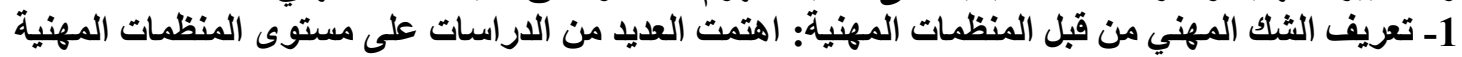

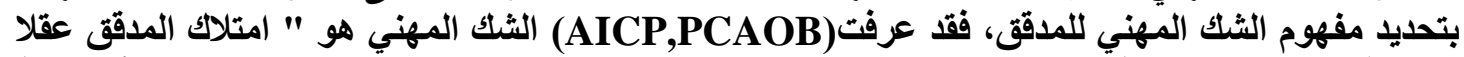

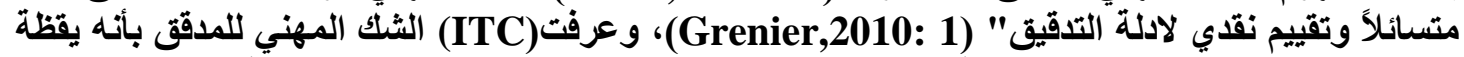

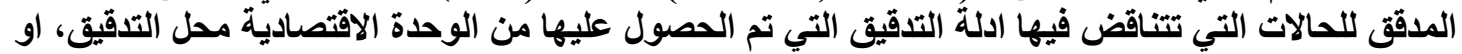

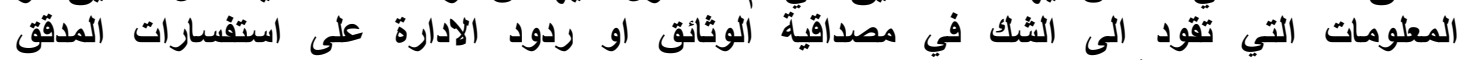

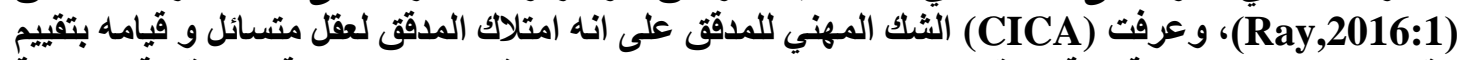

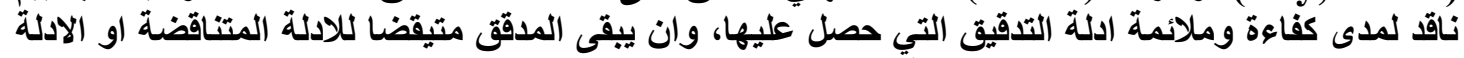

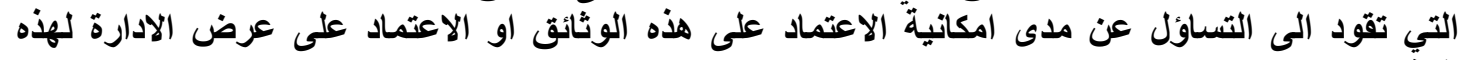

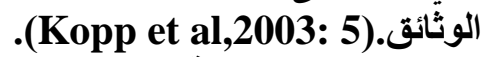

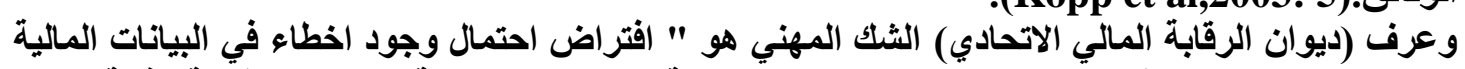

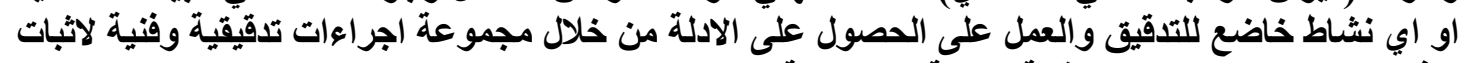

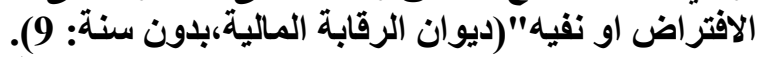

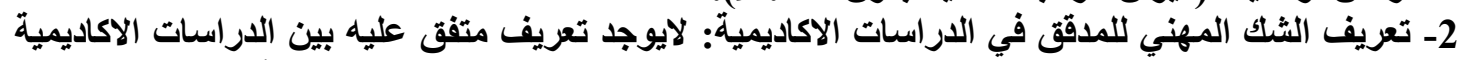

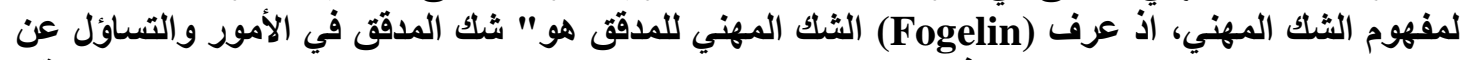

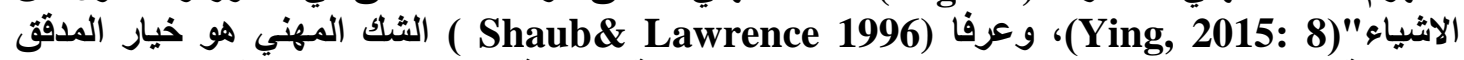

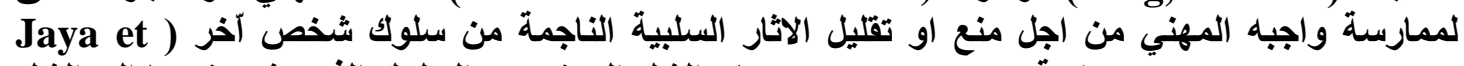

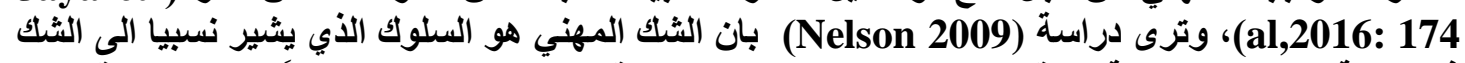

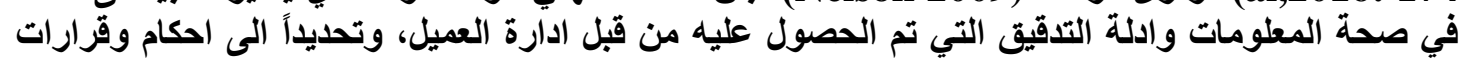

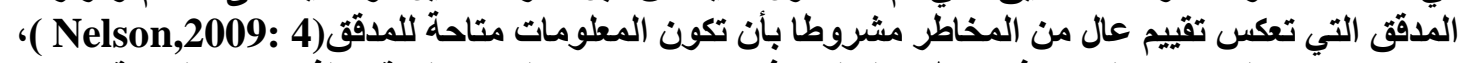

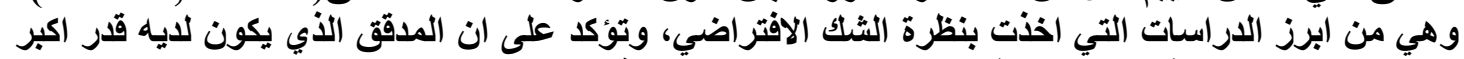

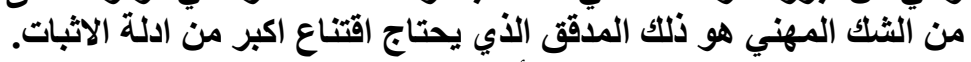

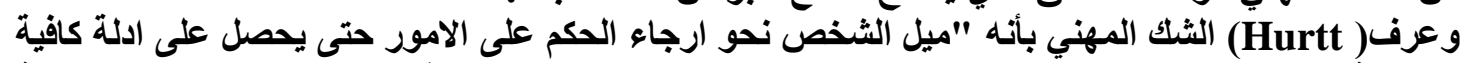

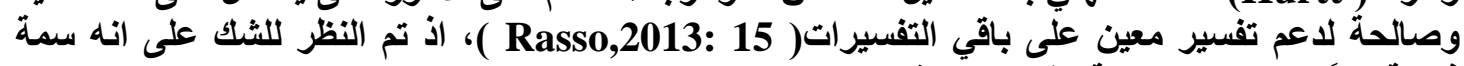

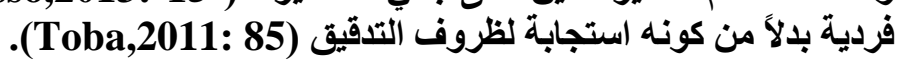

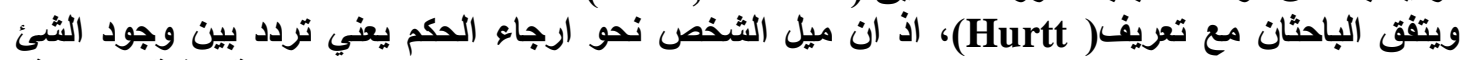

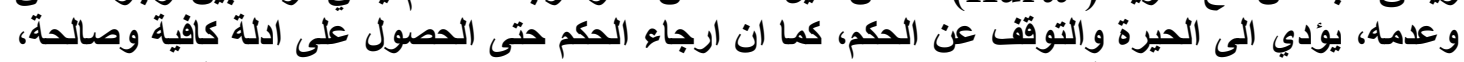

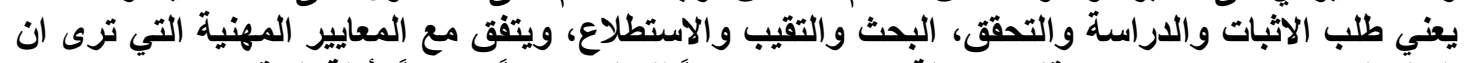

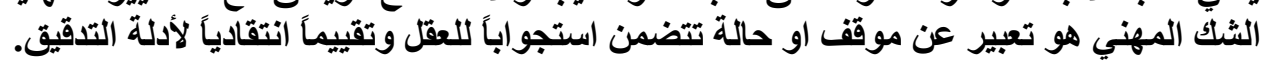

يوجد اتفاق بين عدد كبير من الباحثين على الهية الثئ الثئ المهني اثناء الممارسة المهنية في مجالات

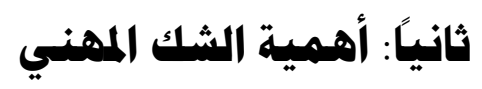

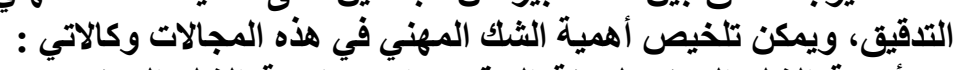

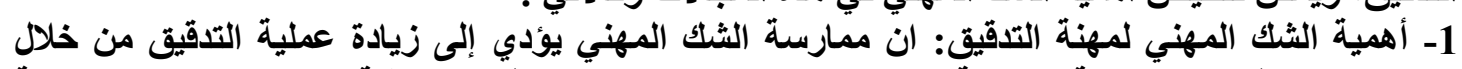

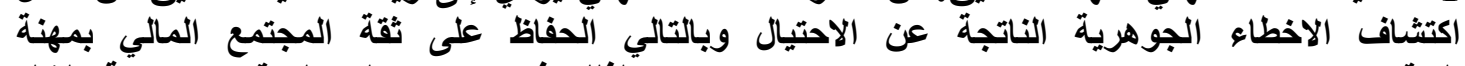

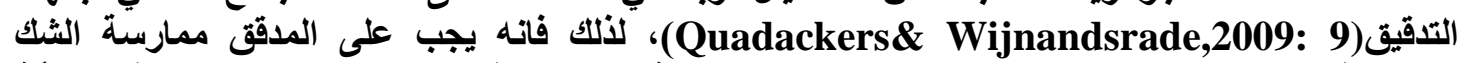

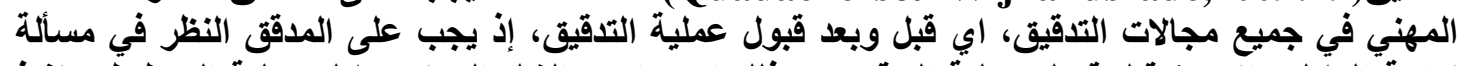

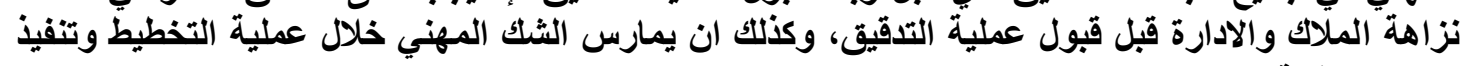

إجراعات التدقيق. 


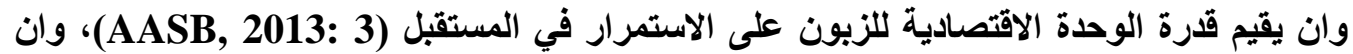

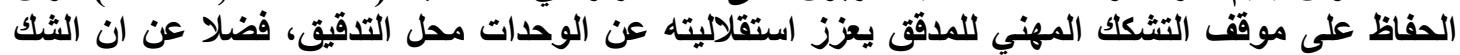

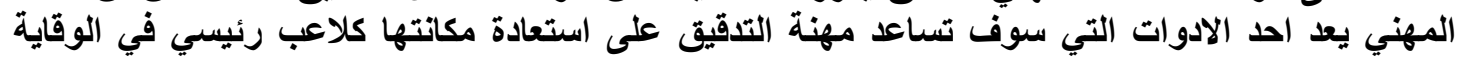
وكثف عمليات الاحتيال (الصباغ وشرف، الفئ 2014: 209).

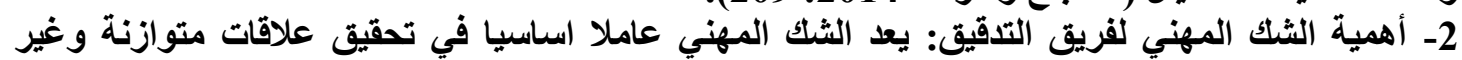

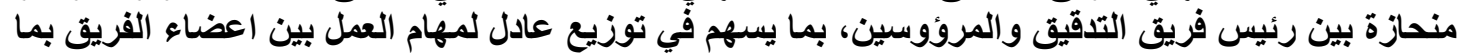

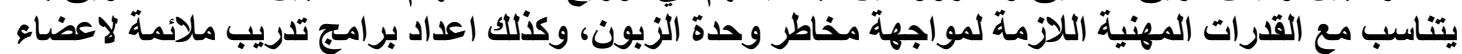

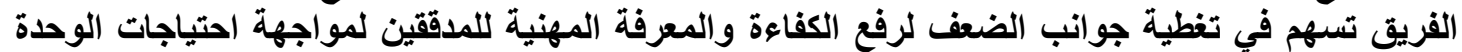

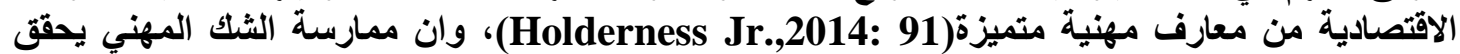

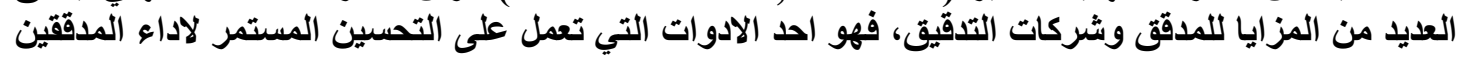

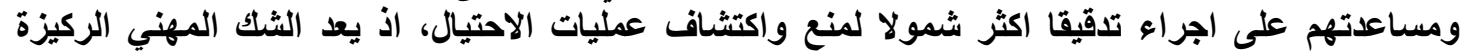

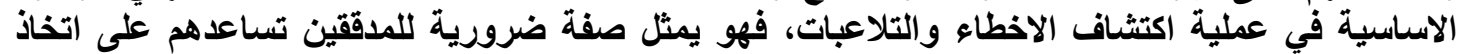

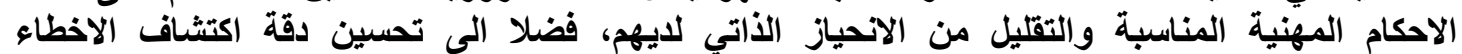

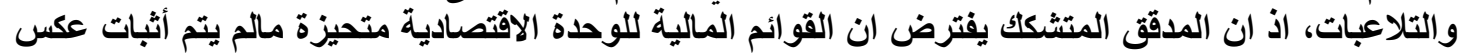

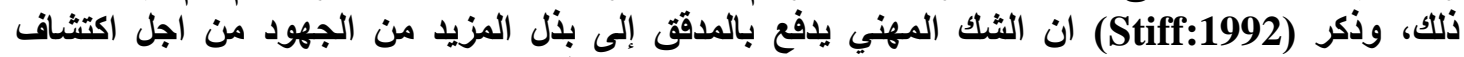

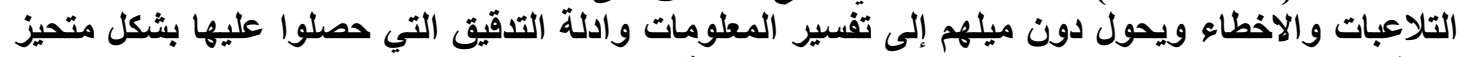

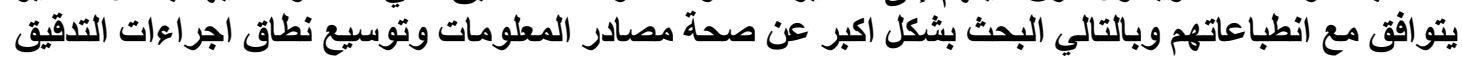

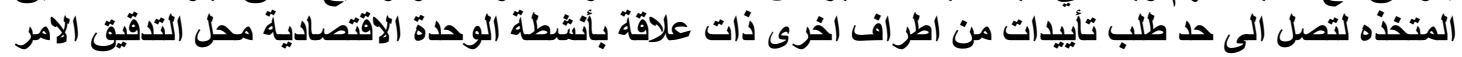

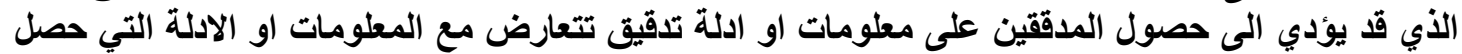

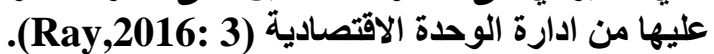
3- أهمية الثكك المهني لمستخدمي التقارير المالية: يلعب الثكائك المهني دوراً هاما في تحقيق فوائد لمستخدمي

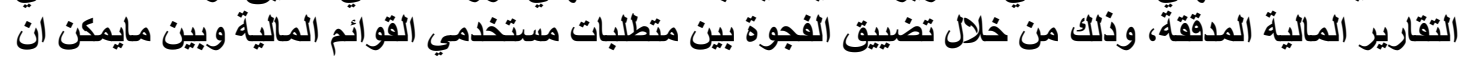

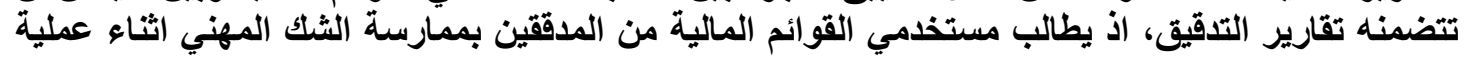

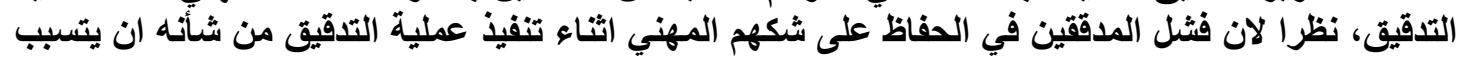

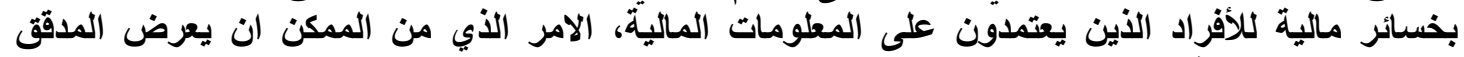

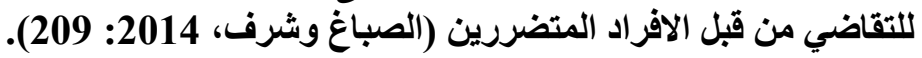

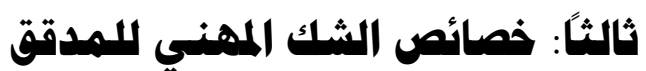

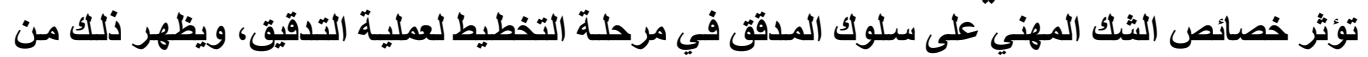

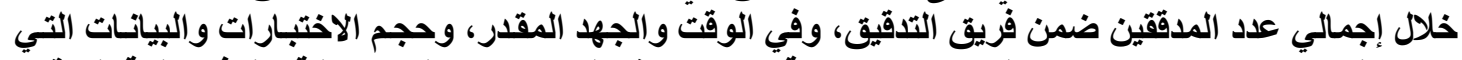

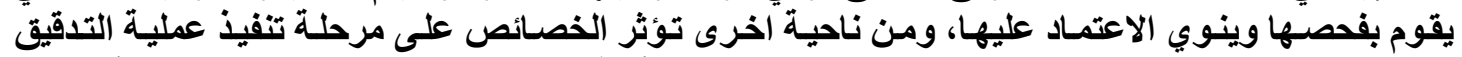

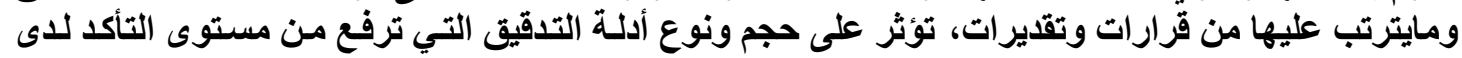

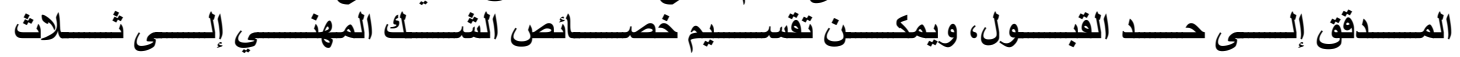
مجموعات (Hussin\&Iskandar,2015:70)هي:

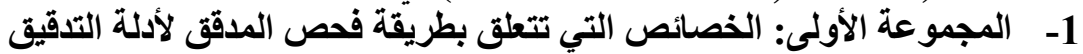

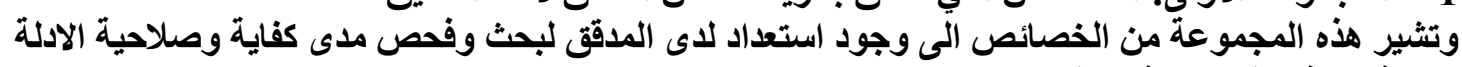

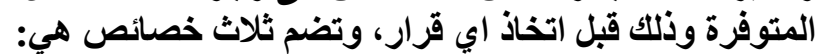

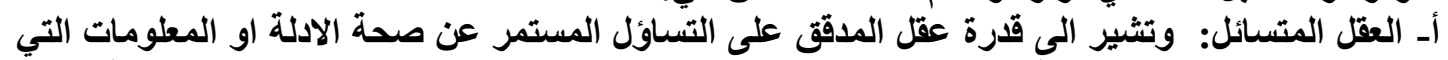

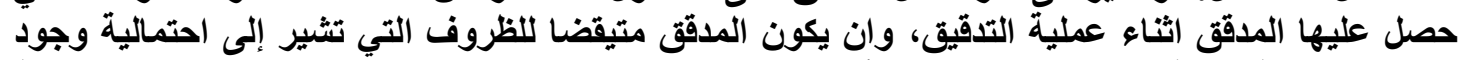

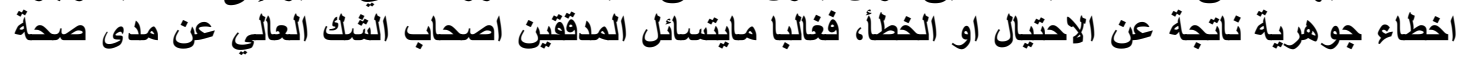
وموثوقية ادلة التدقيق التي حصلوا عليها والتي التئي تدعم الراي الذي يقائي التدموه (IFAC,2010:27). 
وتظهر تلك الخاصية واضحة في الكثير من معايير التدقيق التي تعرضت للثك المهني، اذ ان المعيار

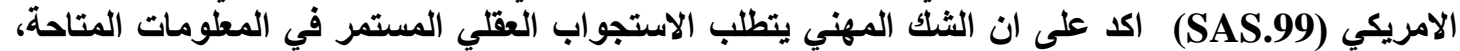

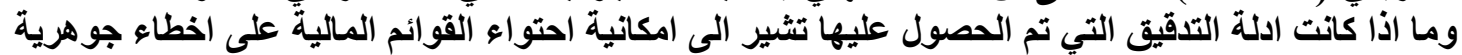
نتيجة الاحتيال ( AICPA,2002 )، فضلا عن المعيار الدولي(ISA 240) الذي الشار الى ان النئل التثك المهني

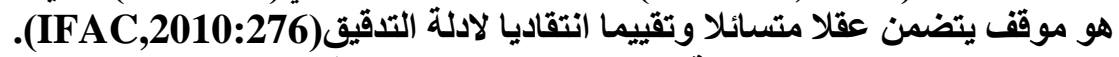

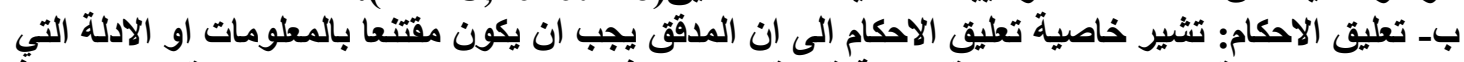

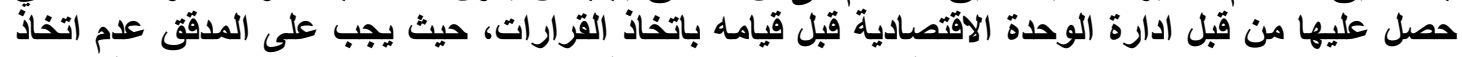

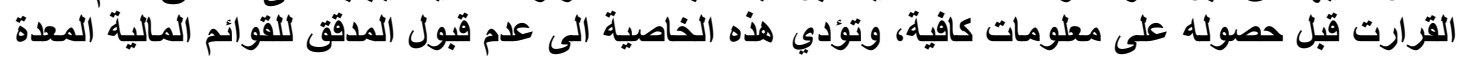

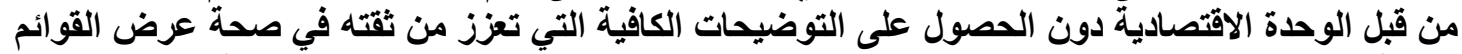

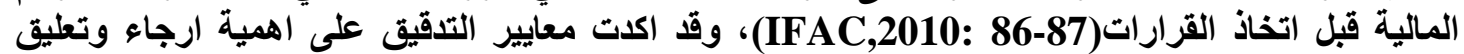

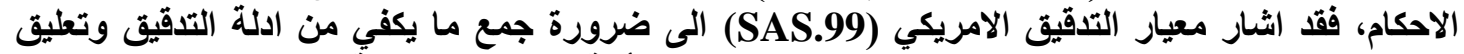

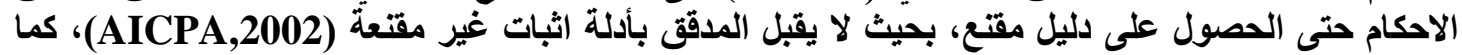

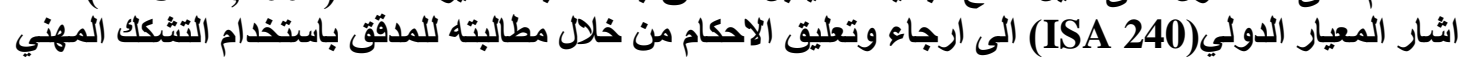

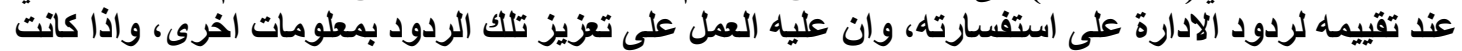

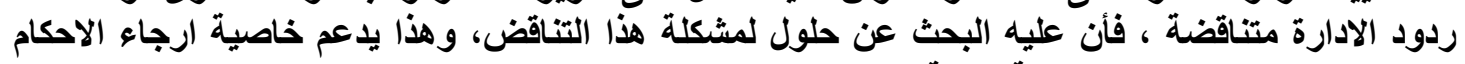
والقرارات حتى الحصول على عنى ادلة مقنعة (IFAC,2010:278).

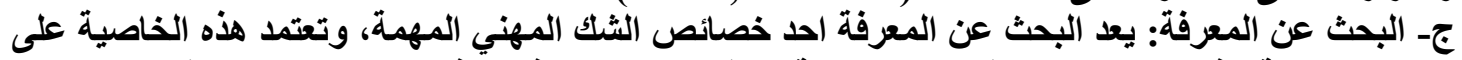

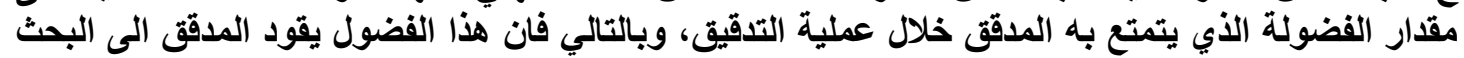

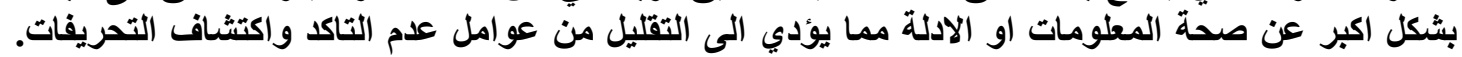

(Hussin \& Iskandar, 2015: 70)

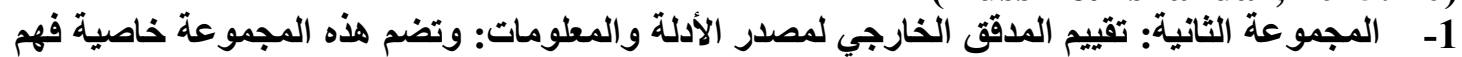

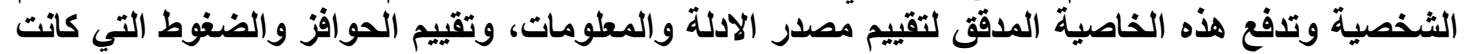

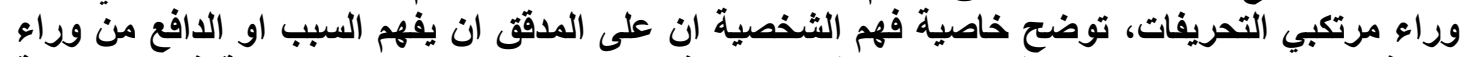

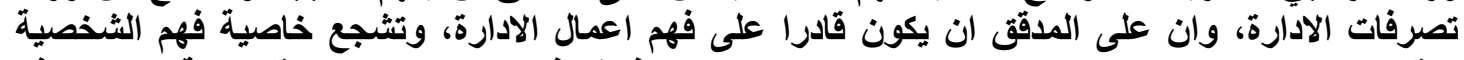

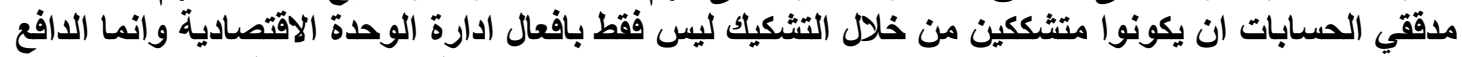

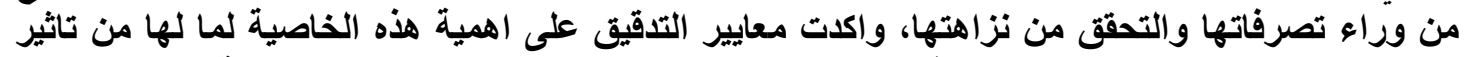

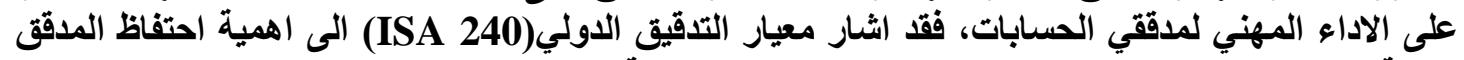

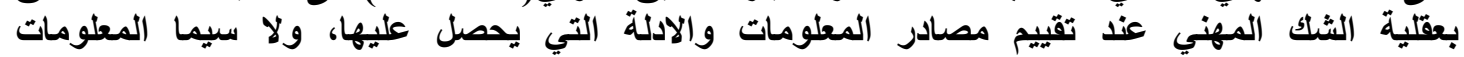

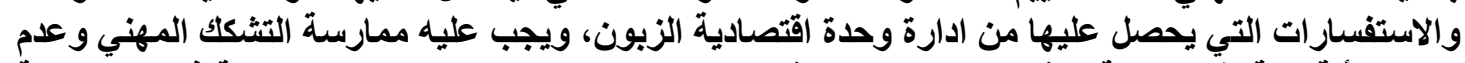

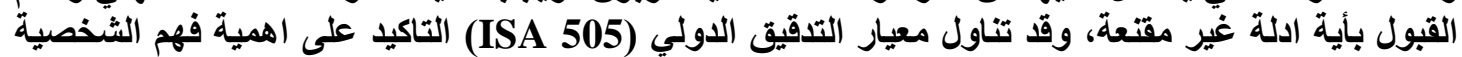

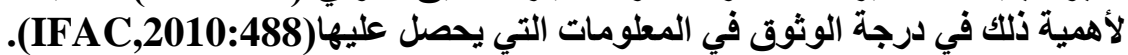

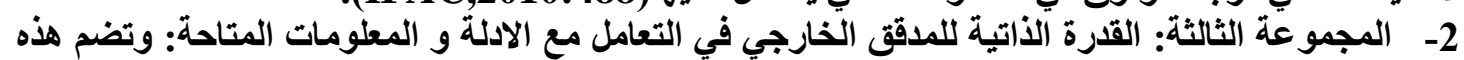

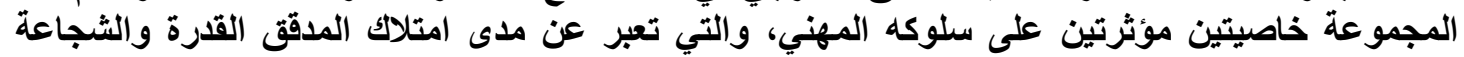

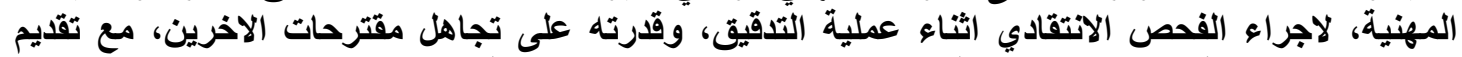

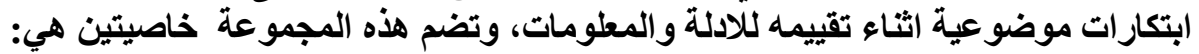

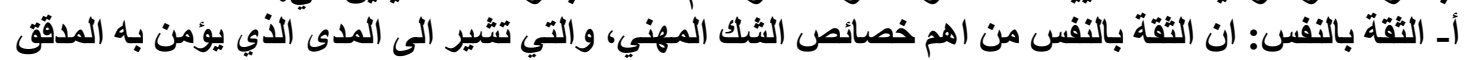

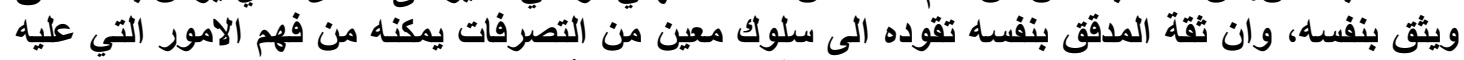

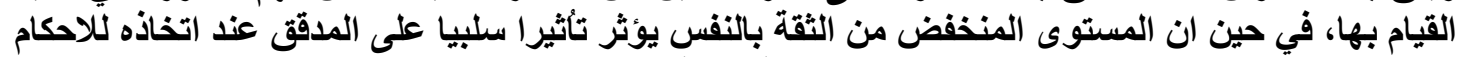

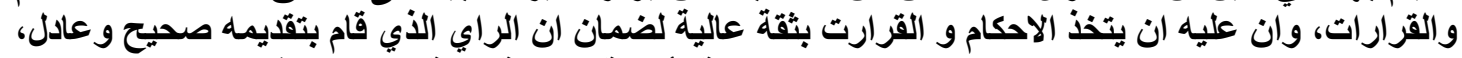

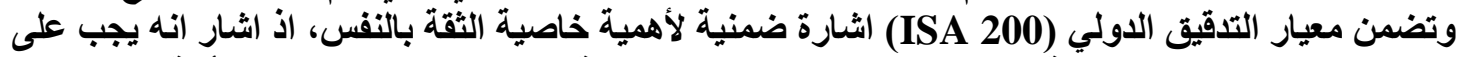

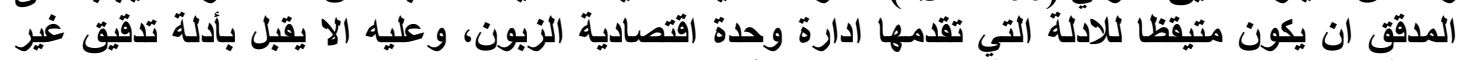

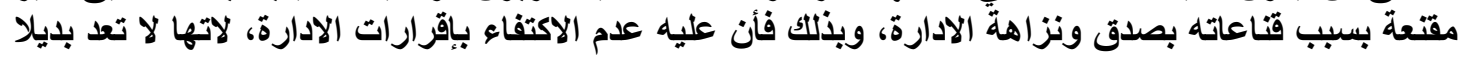

عن الحصول على ادلة تدقيق كافية وصالحة للوصول ولئل الى الاستتناجات المعقولة (IFAC,2010:498). 
أ- الاستقلال الذاتي: تثير هذه الخاصية بانه على المدقق ان يتخذ القرارات بشجاعة وحيادية فيما يتعلق بتقييم

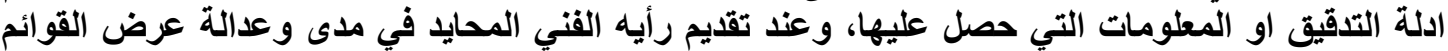

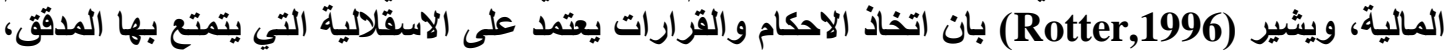

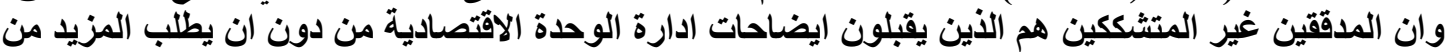

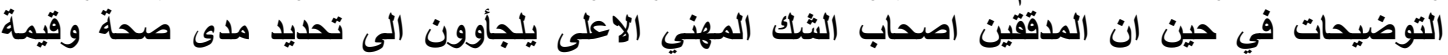

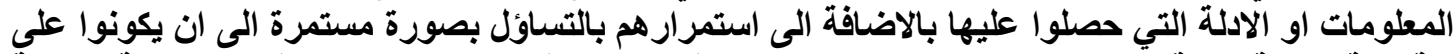

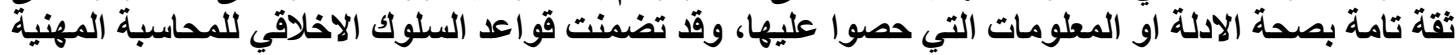

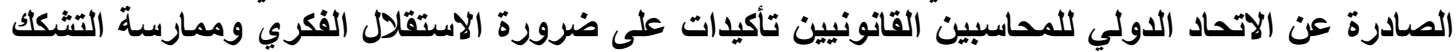

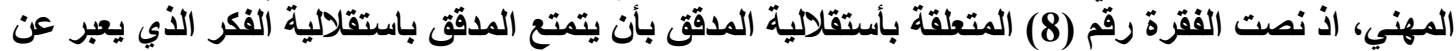

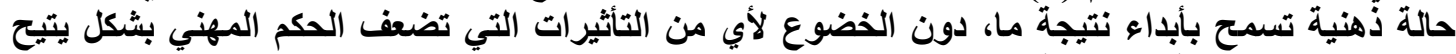
للفرد التصرف بنزاهة وممارسة التشكك المهني(IFAC,2010:50).

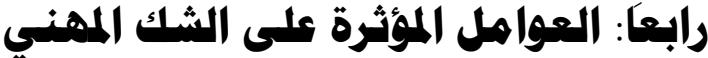

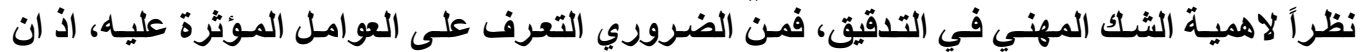

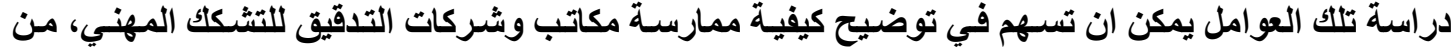

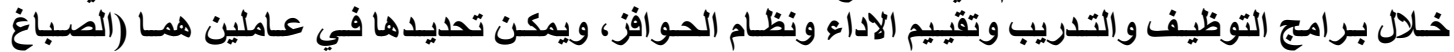

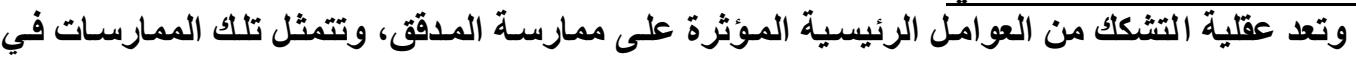

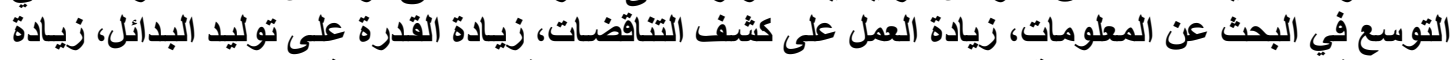

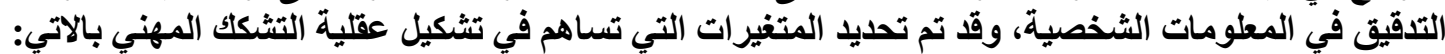

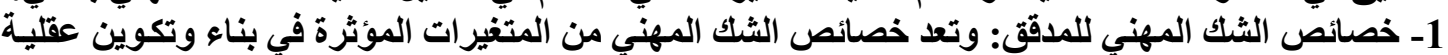

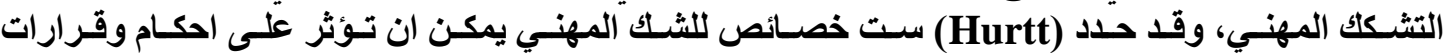

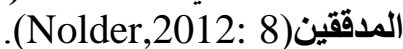

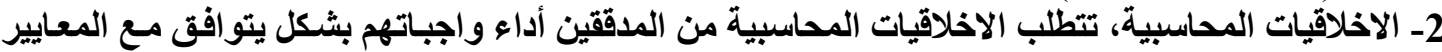

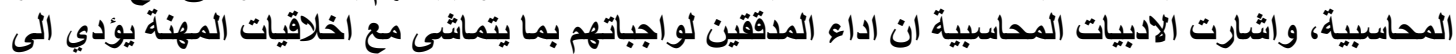

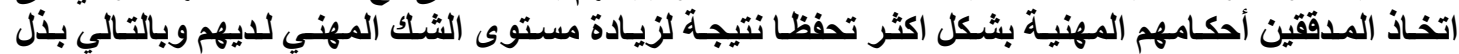

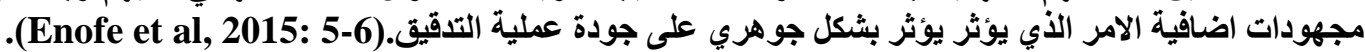

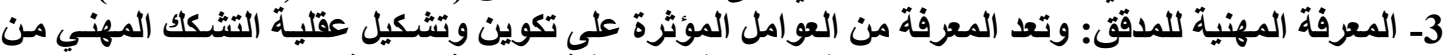

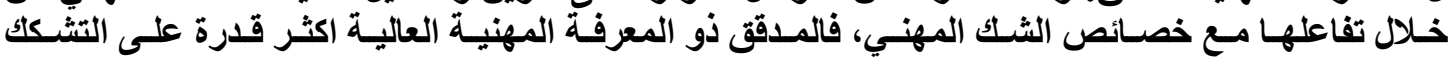

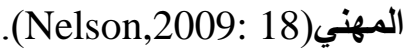

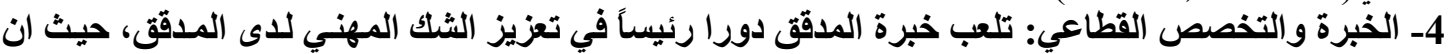

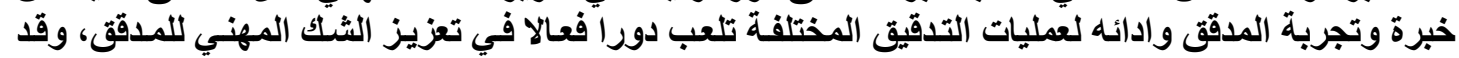

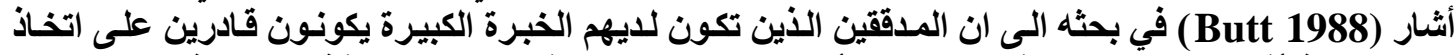

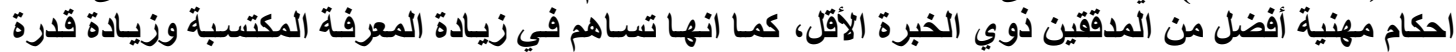

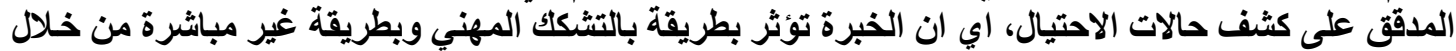

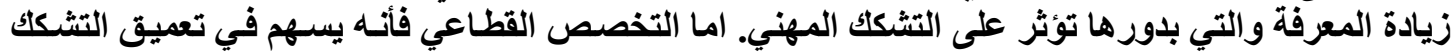

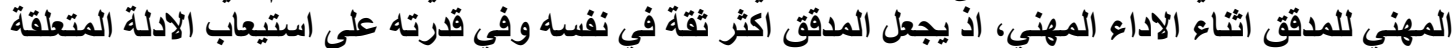

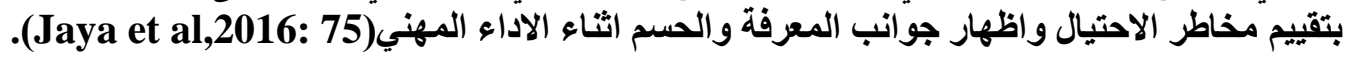


5- اجور عملية التدقيق: اذيرى الكثير من الباحثين ان التهديد الاكبر على الاستقلالية والثك المهني للمدقق

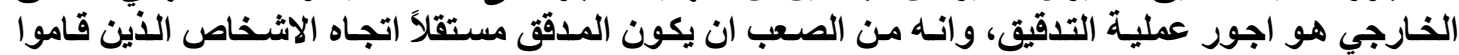

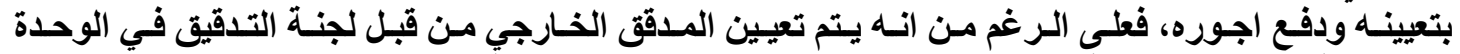

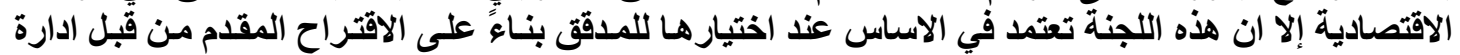

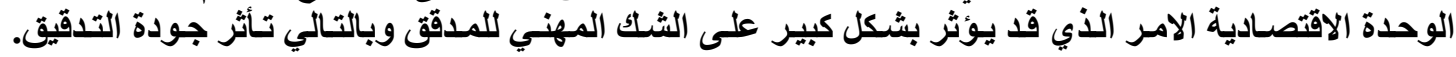

(Enofe et al, 2015: 5-6)

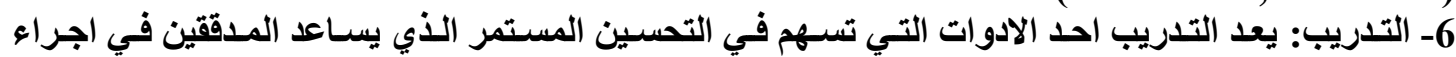

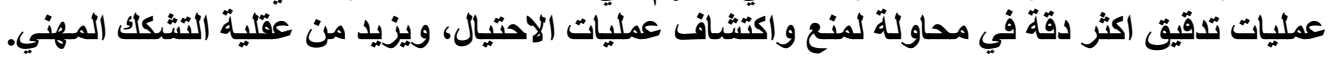

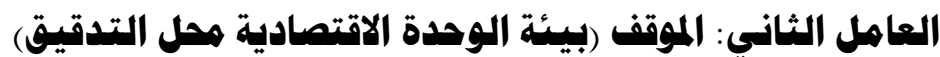

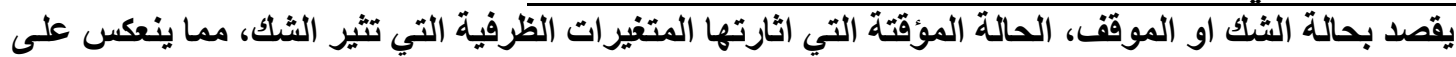

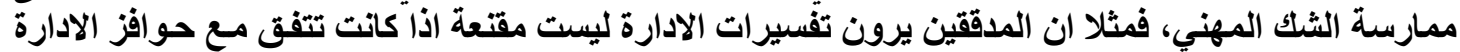

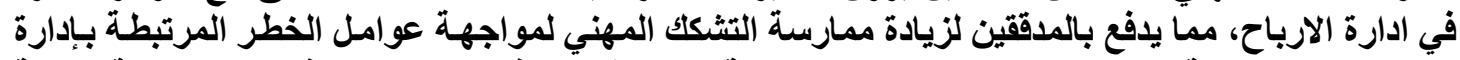

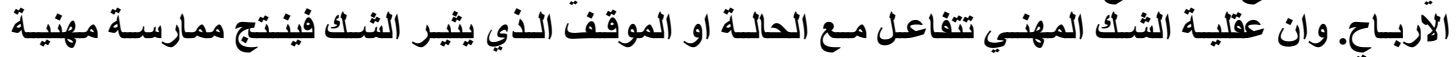

متثككة) (Enofe et al, 2015: 5-6).

\section{المهور الثالث/ جودة التدقيت والعواهل المؤثرة فيها}

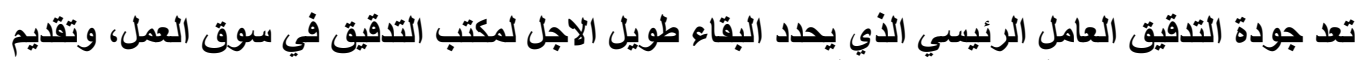

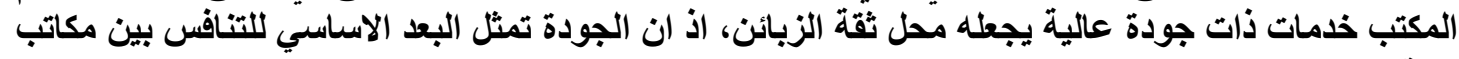

اولاً: هفهوم جودة التدقيـق الخارجي

لم يتم تحديد مفهوم معين لجودة التدقيق متفق عليه من قبل المنظمات المهنية والباحثين، فقد تم المثاء

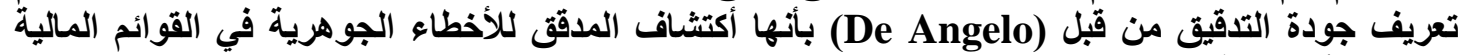

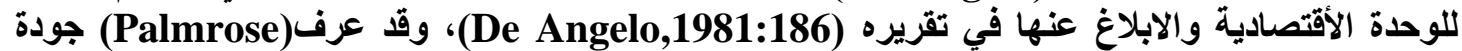

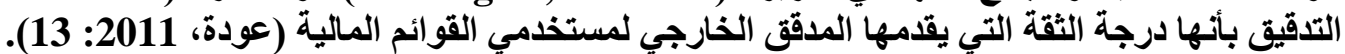

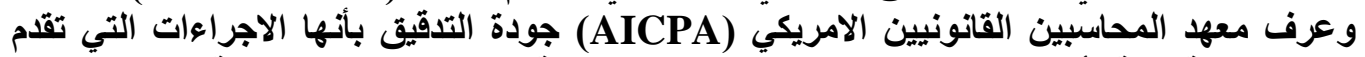

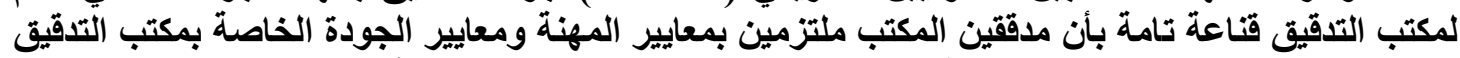

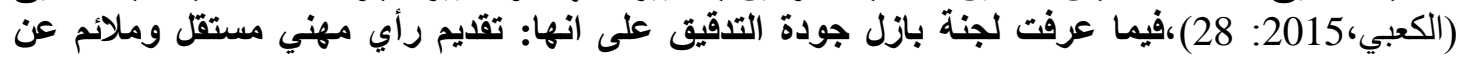

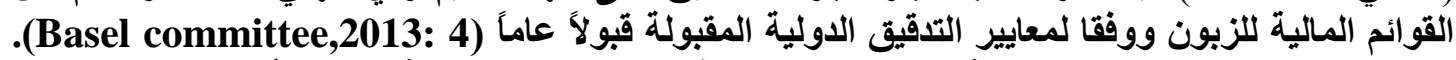

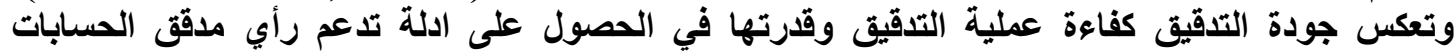

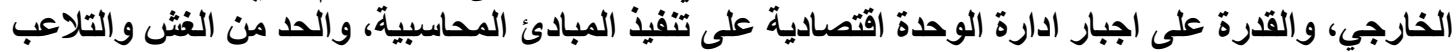

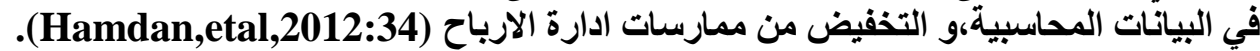

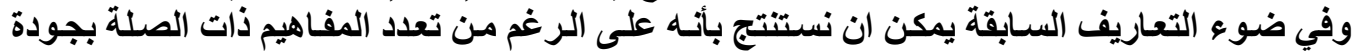

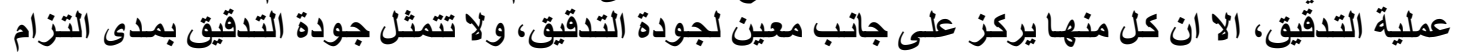

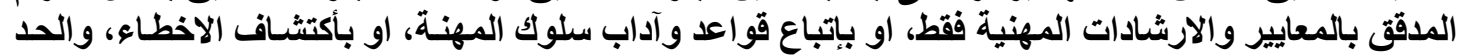

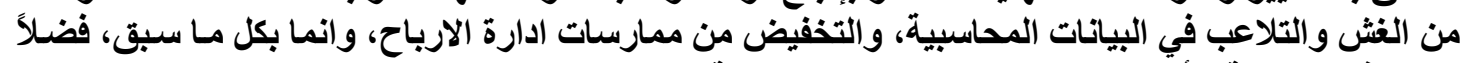
عن توفير الحماية للأطراف المستفيدة من التقات التقارير المالية.

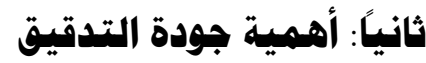

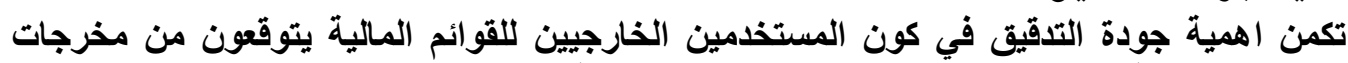

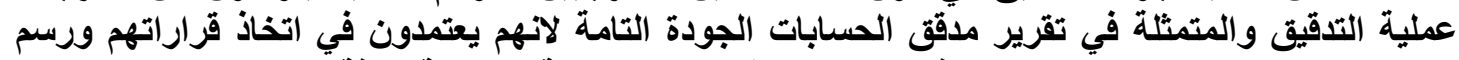

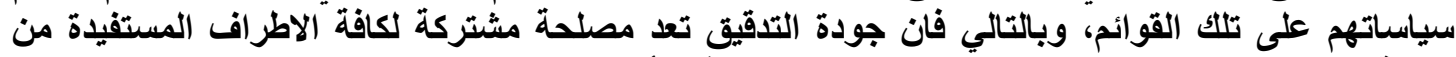
عملية التقيق (عبد العزيز،2016: 47 )، ويمكن بيان هذه الأطراف بالاتي: 
1- أدارة الوحدة الأقتصادية: أن جودة التدقيق تساعد أدارة الوحدة الأقتصادية على تحسين جودة التذقيق

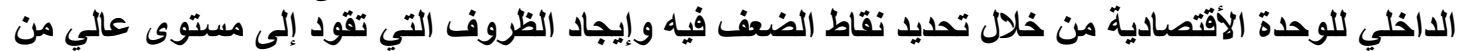

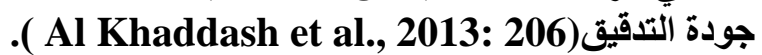

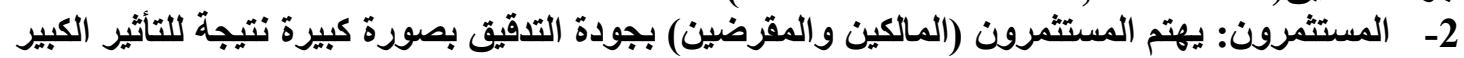

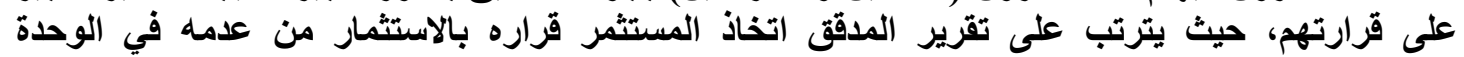

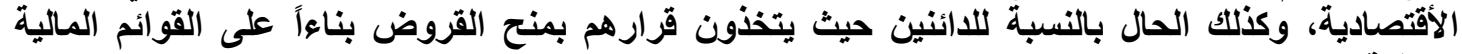

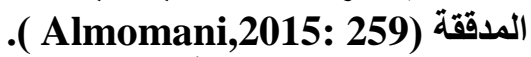
3- مكاتب التدقيق: ان أهتمام مكاتب التدقيق بجودة الخدمات التي يقدموها ينعكس بثكل أيجابي على ارباح

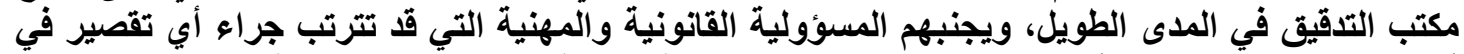

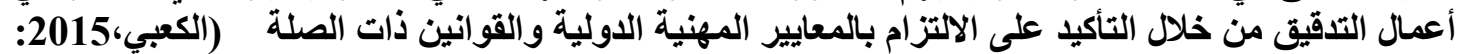

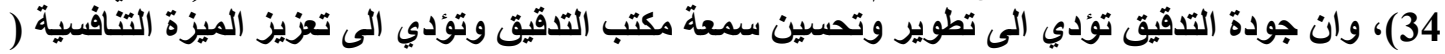

.(Almomani,2015: 258

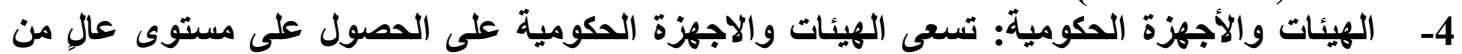

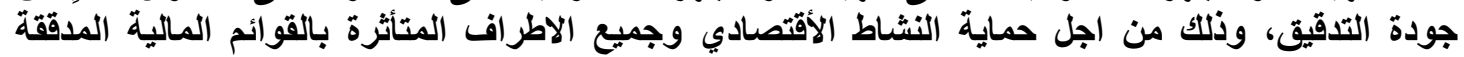

. Almomani,2015: 259)

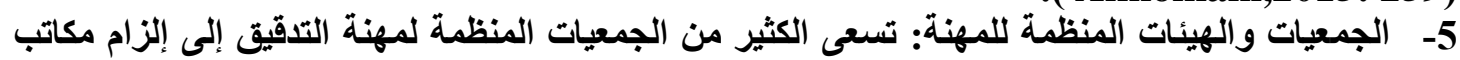

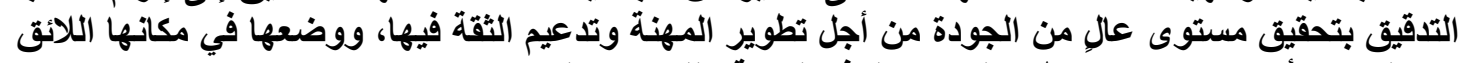

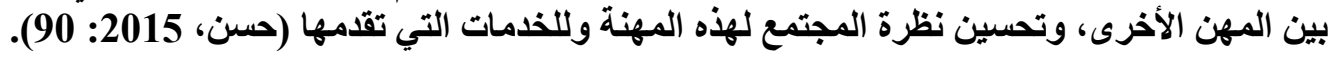

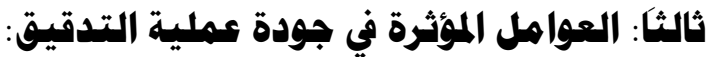

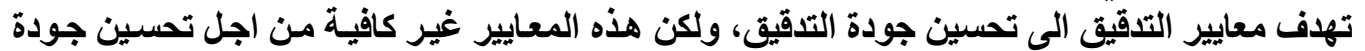

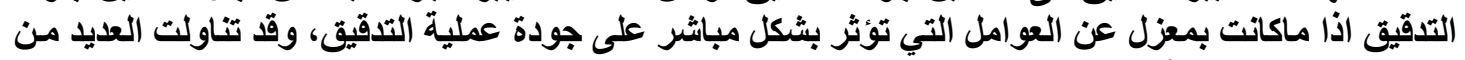

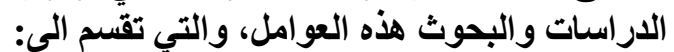

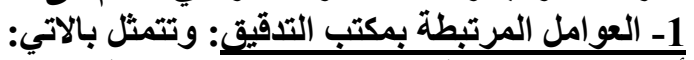

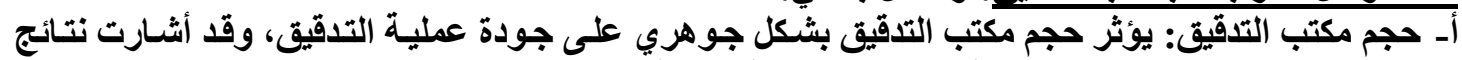

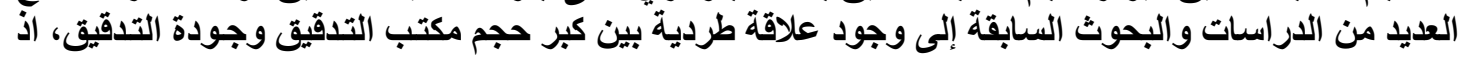

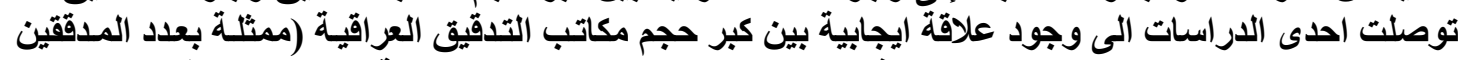

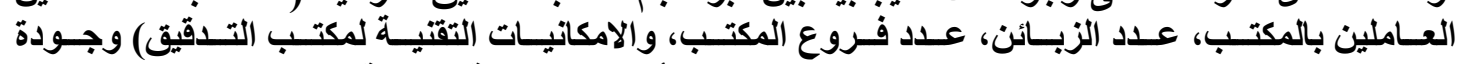

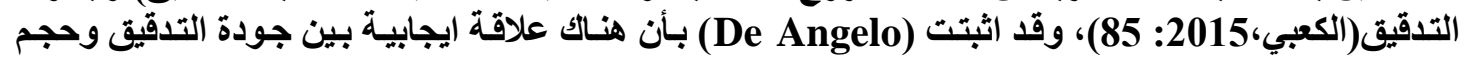

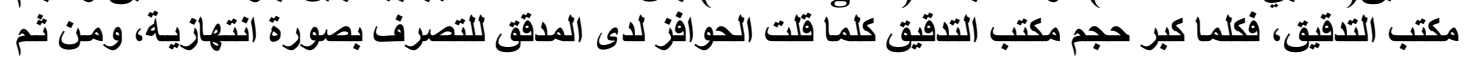

تحسين جودة التدقيق (De Angelo,1981: 44).

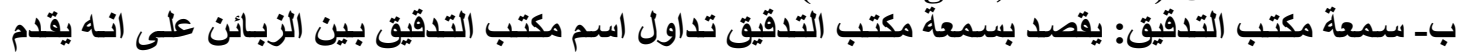

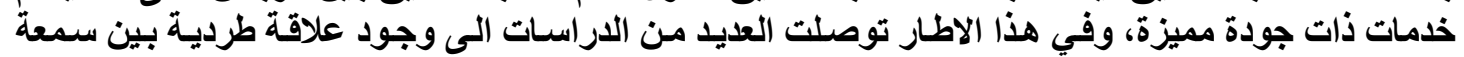

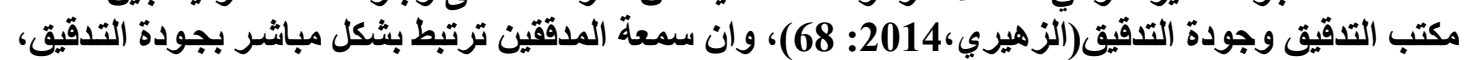

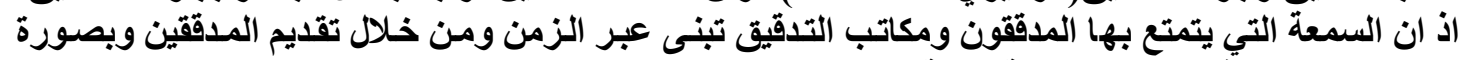

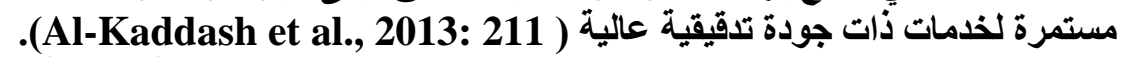

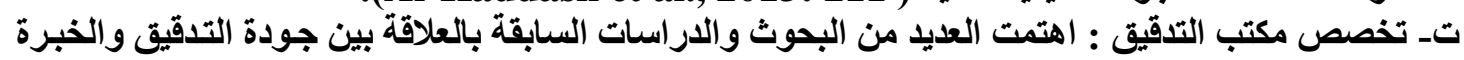

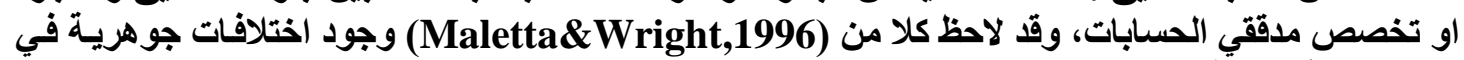

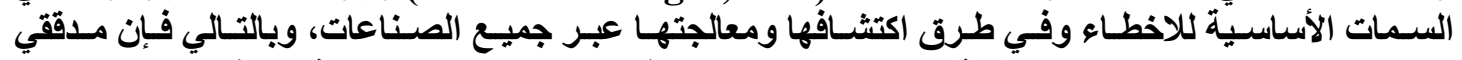

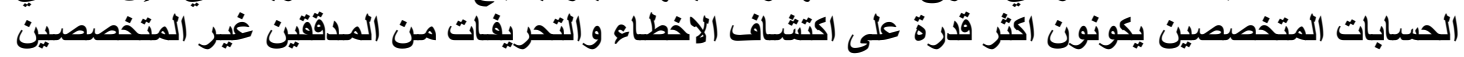

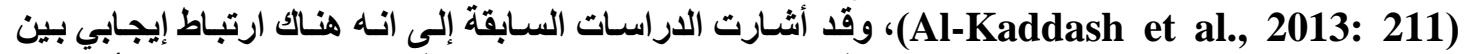

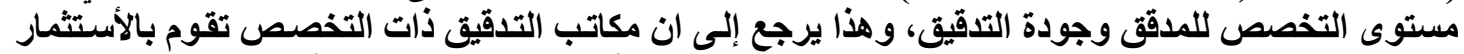

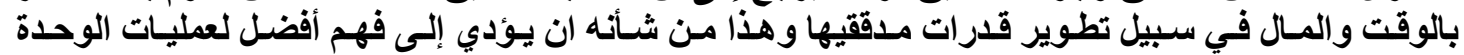

الأقتصادية والمخاطر المحيطة ويالتالي تحسين جودة التدقيق (Anis,2014: 109). 


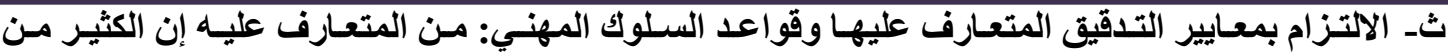

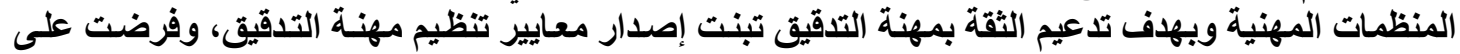

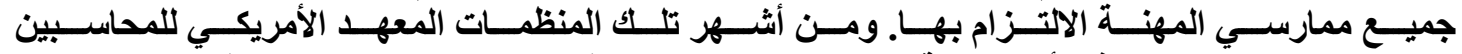

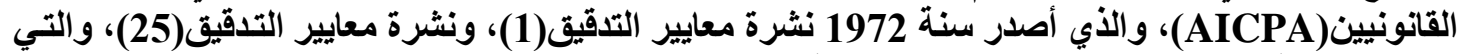

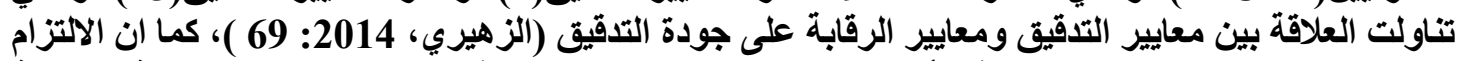

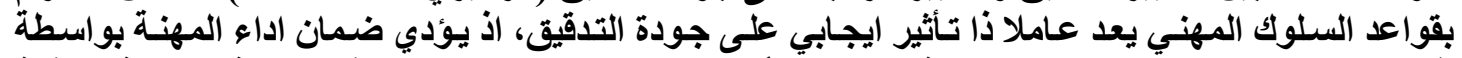

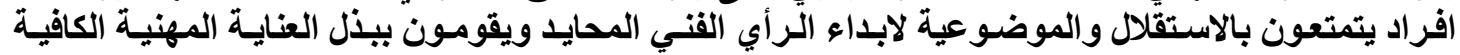

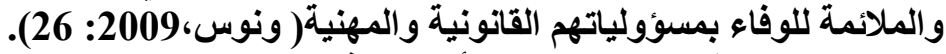

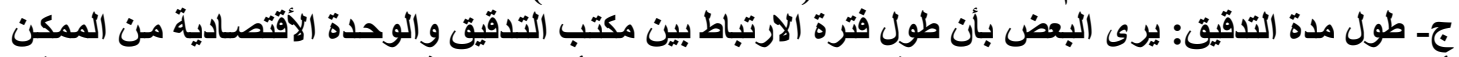

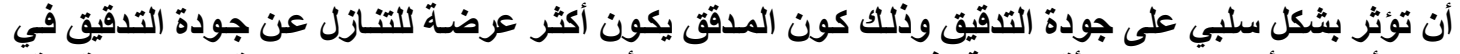

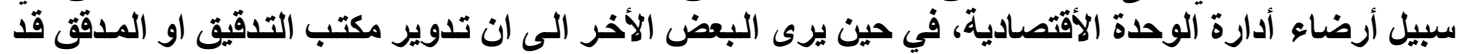

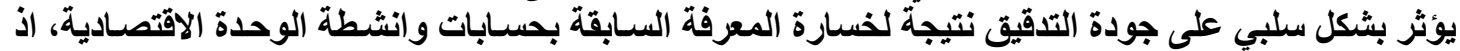

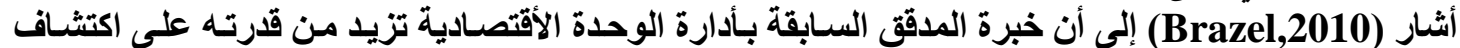

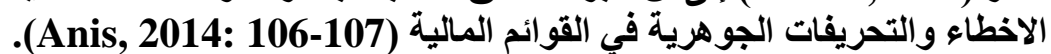

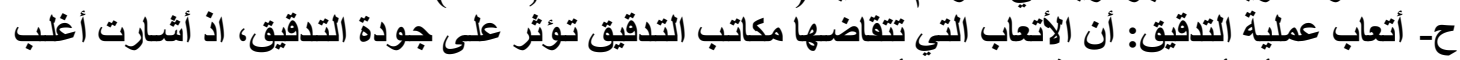

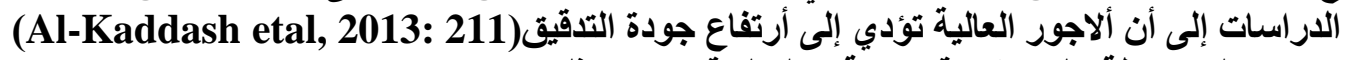

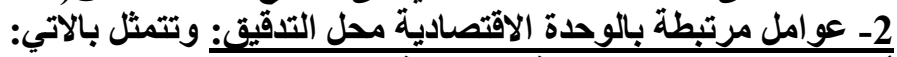

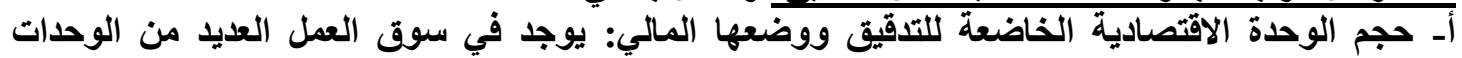

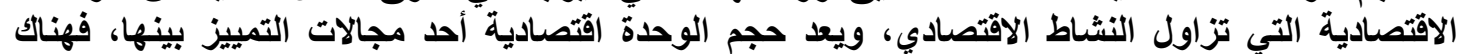

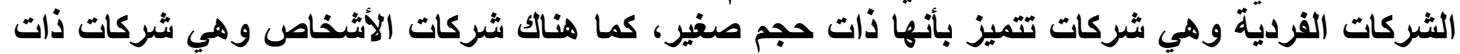

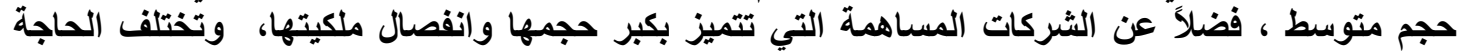

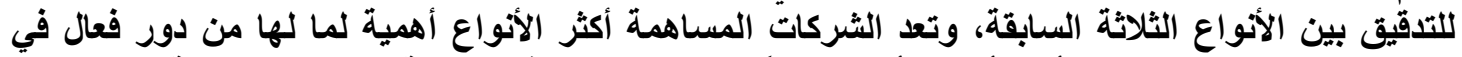

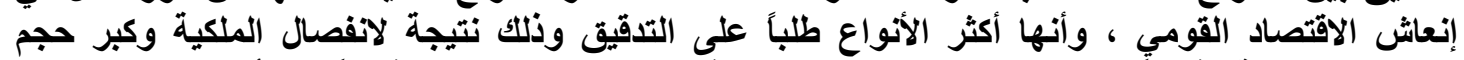

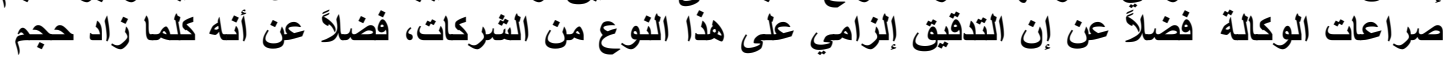

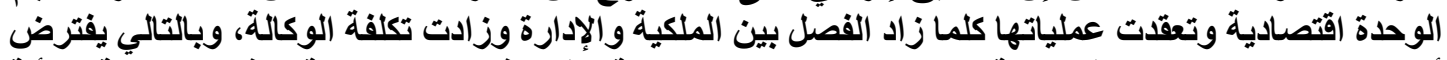

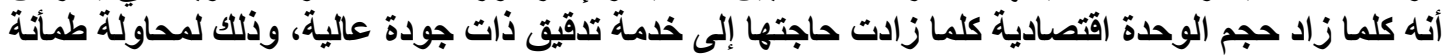

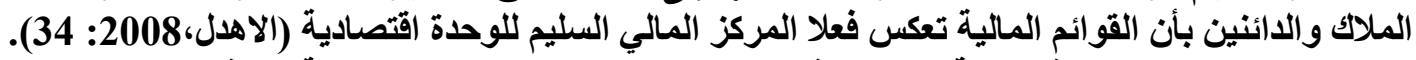

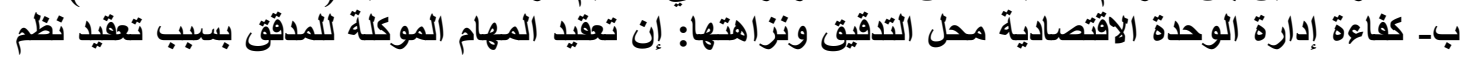

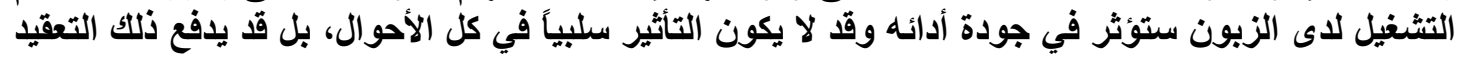

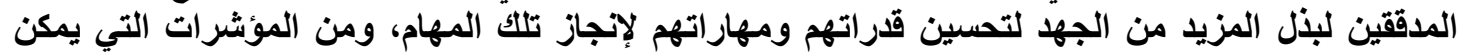

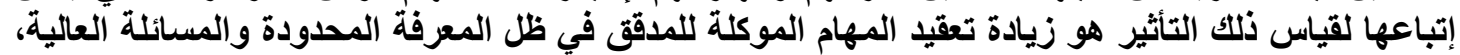

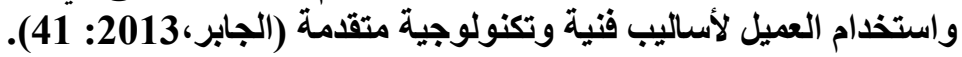

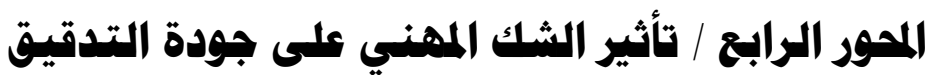

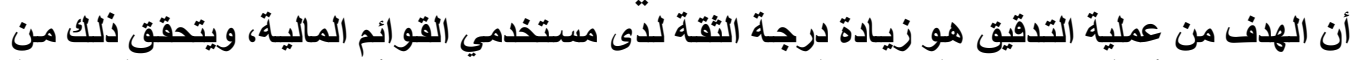

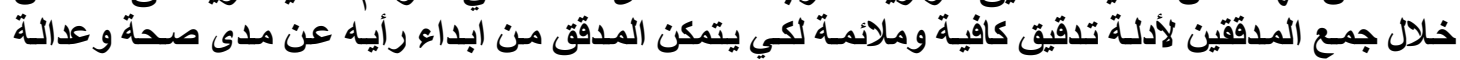

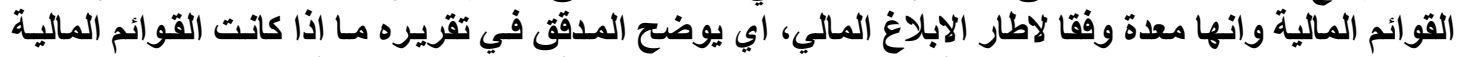

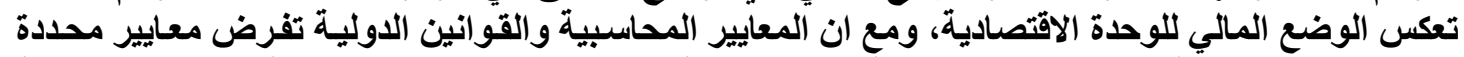

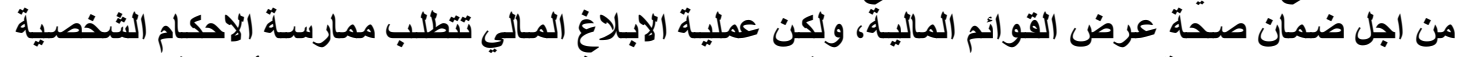

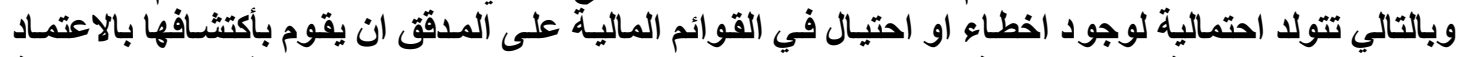

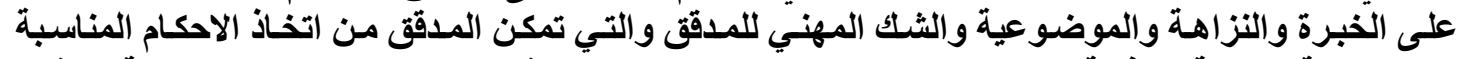

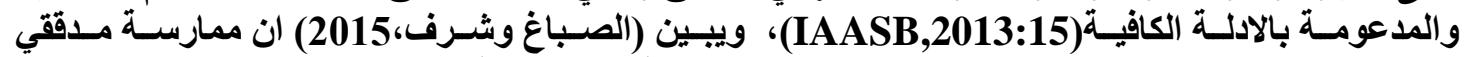
الحسابات للثك المهني من الممكن ان يساهم في استعادة مهنة التدقيق لثقة المجتمع المالي بها. 


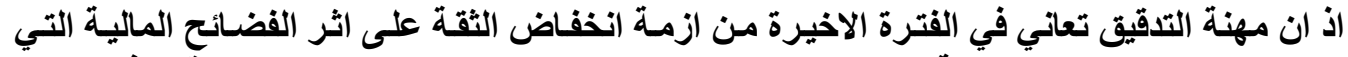

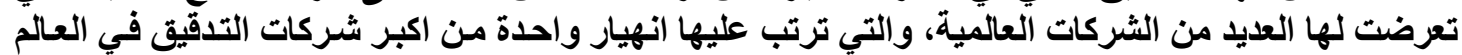

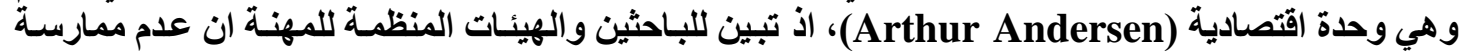

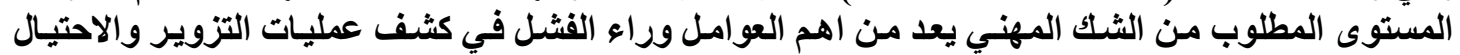
المالي (الصباغ وشرف، المطوب من 2015: 23).

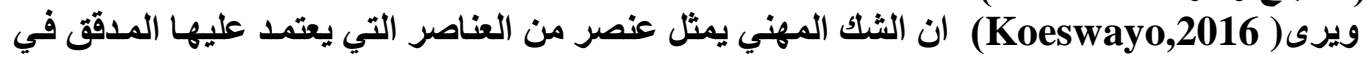

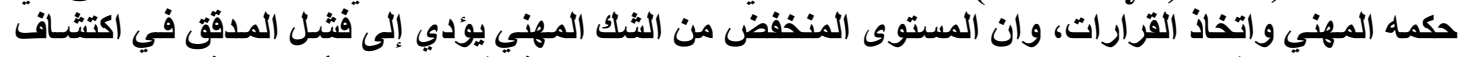

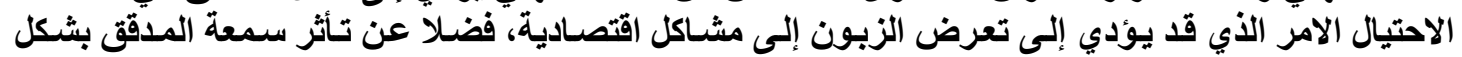

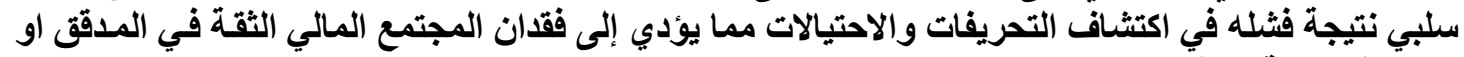

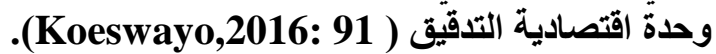

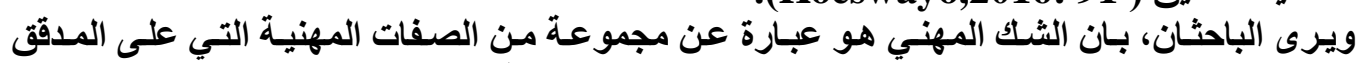

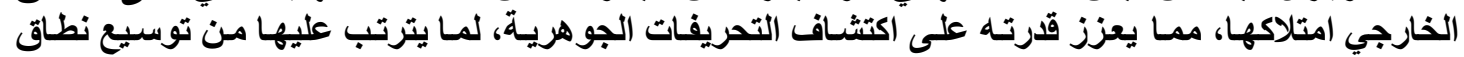

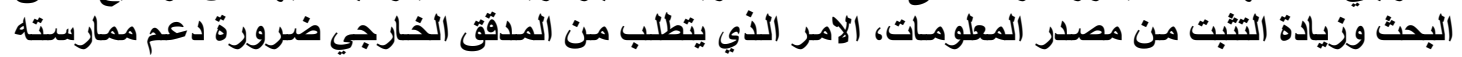

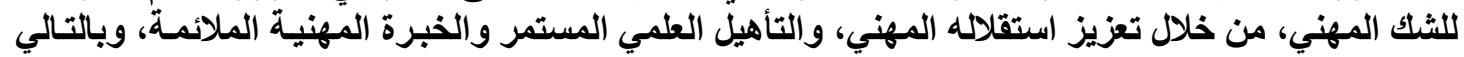

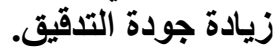

\section{الحهور الخاهس/قياس تأثير خصائص الشك المهني على جودة التدقيق في شركات وهكاتب التدقيق العراقية}

\section{اولاً: قياس خصائص الشك المهني في شركات ومكاتب التدقيق العراقية فئية}

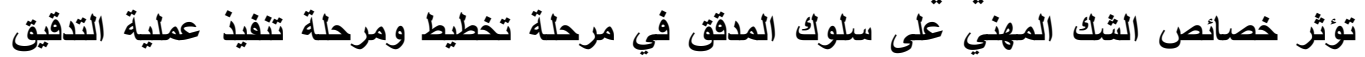

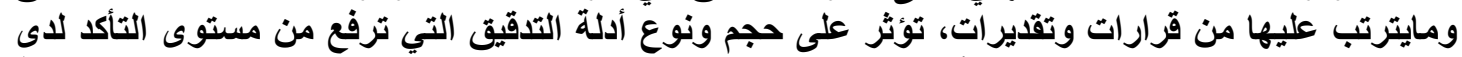

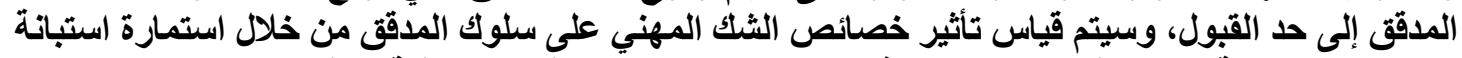

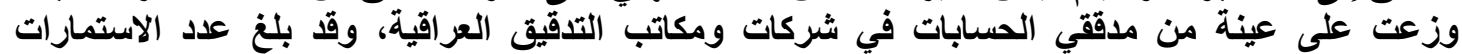

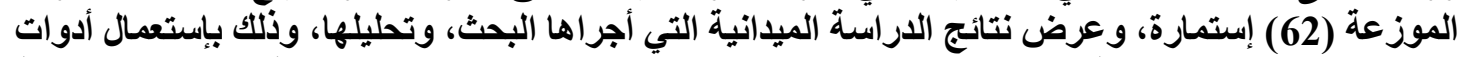

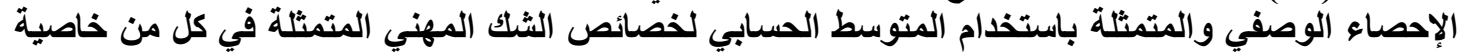

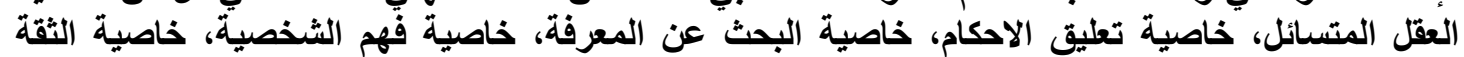
بالنفس، واخيرا خاصية الاستقلال الأتي، وذلك لتحديد مدى توافر تلك الخصائص لادى المدققين، كما هي مبينة

جدول (1) مدى توافر خصائص الثكك المهني لاى افراد عينة البحث

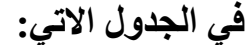

\begin{tabular}{|c|c|c|c|c|c|}
\hline \multirow[b]{2}{*}{ الترتيب } & \multicolumn{3}{|c|}{ الوصف الإحصائي للبيانات } & \multirow[b]{2}{*}{ خصائص الثك المهني } & \multirow[b]{2}{*}{ التسلسل } \\
\hline & معامل الاختلاف & المعياري & الحستابي & & \\
\hline 4 & 13.083 & 0.5 & 4.28 & خاصية العقلّ المتسائل & 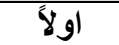 \\
\hline 1 & 15.562 & 0.668 & 4.75 & خاصية تعليق الاحكام & ثانياً \\
\hline 3 & 14.782 & 0.6582 & 4.47 & خاصية البحث عن المعرفة & ثاثثاً \\
\hline 2 & 15.138 & 0.6518 & 4.67 & خاصية فهم الثخصية & رابعاً \\
\hline 6 & 25.04 & 0.817 & 3.1 & خاصية الثقة بالنفس & خامساً \\
\hline 5 & 16.272 & 0.798 & 3.46 & خاصية الاستقلال الذاتي & سادساً \\
\hline & & 0.682 & 4.15 & الإجمالي & \\
\hline
\end{tabular}




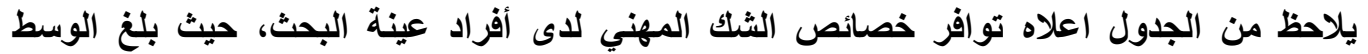

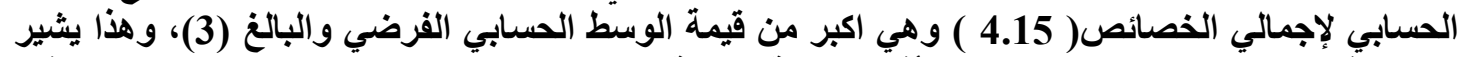

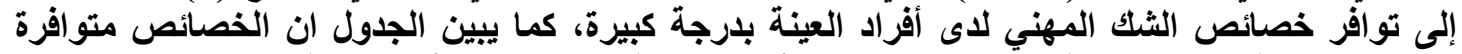

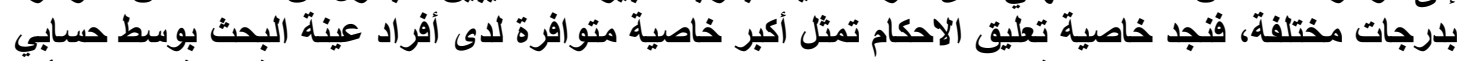

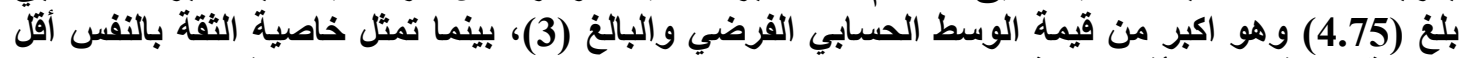
خاصية متوافرة لدى أفراد عينة البحث بوسط حسابي بلغ (

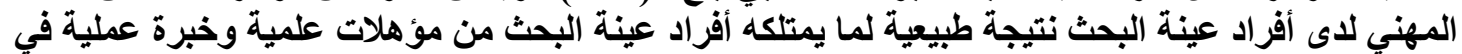

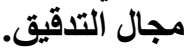

\section{ثانياً: قياس تأثير خصائص الشك المهني على جودة التدقيتق}

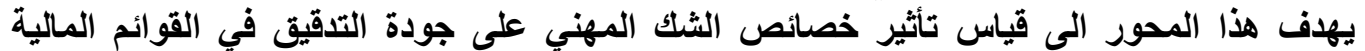

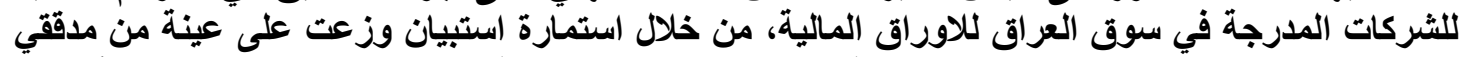

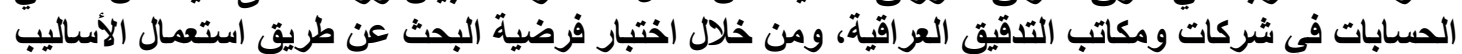

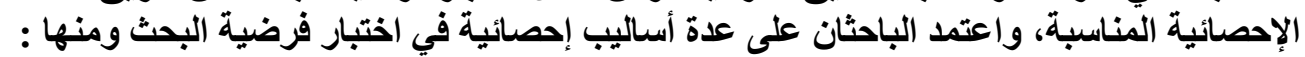

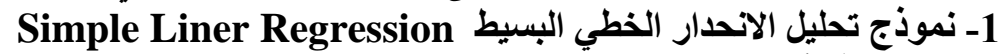
$\mathbf{Y}=\mathbf{B}_{0}+\mathbf{B}_{1} \mathbf{x}_{1}$ لتحديد درجة تأثير المتغير المستِقل على المتغير التابع ، ويمكن كتابته بالثكل الأتي :

وأن تحليل الانحدار البسيط يعتمد على وجود فرضيتين:

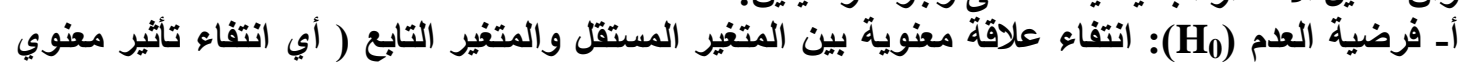

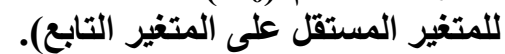

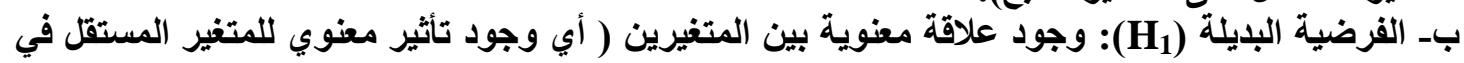
المتغير التابع).

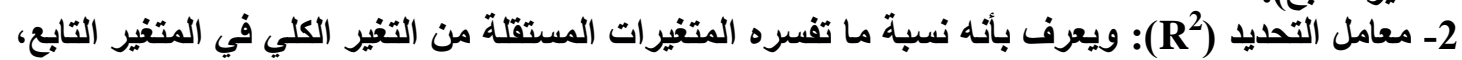

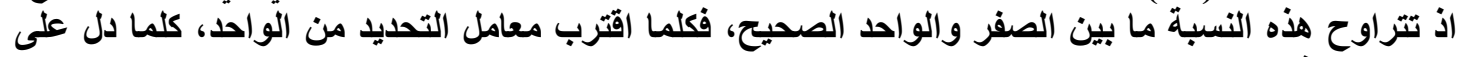

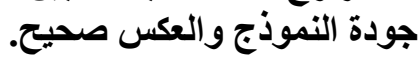

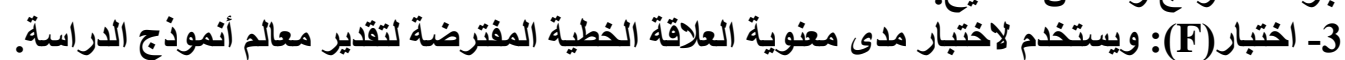

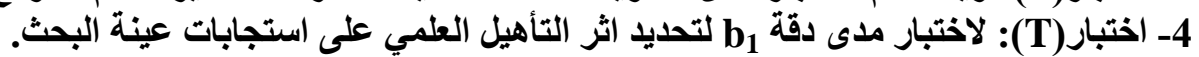
ويمكن قياس تأثير خصائص الثك المهني على جودة التذقيق وهي:

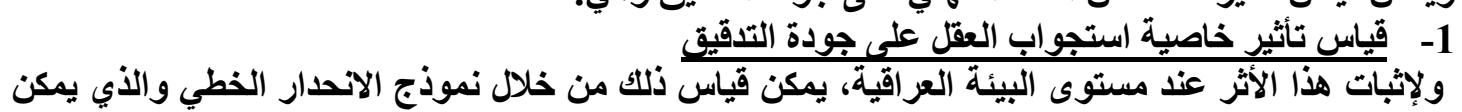
$Y_{t}=3.13+0.27 X_{1}$

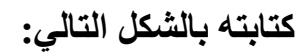

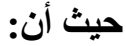

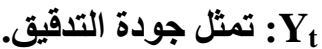
X

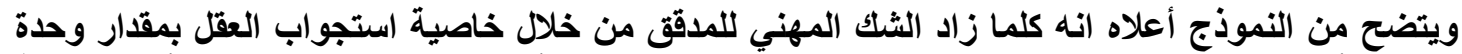

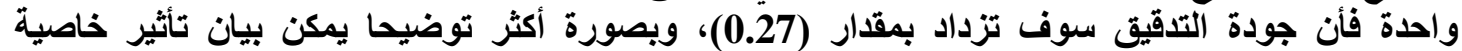
استجواب العقل على جودة التدقيق، من خلان الجدول بلدول الآتي: 


\section{تأثير خمائس الشاله المهني للمدققا على جودة التققيقا}

\begin{tabular}{|c|c|c|c|c|c|c|c|c|c|}
\hline \multicolumn{10}{|c|}{ جدول (2) تأثير خاصية استجواب العقل على جودة التدقيق } \\
\hline قبول (رفض) الفرضية & التحسوبة & الدلالة & $\begin{array}{c}\text { مقيمل } \\
\text { الارتباط } \\
\text { r }\end{array}$ & الدلالة & قالقحسوبة & مقامل & قيمة & $\begin{array}{c}\text { المتتمد } \\
\text { Yتغير }\end{array}$ & $\begin{array}{c}\text { المتغير المستقل } \\
\text { X }\end{array}$ \\
\hline وقبول القرضية العبديلة & 13.98 & رئو & 0.24 & معنوية & 13.92 & 0.06 & 3.13 & التدقيق & خاصية استجواب \\
\hline
\end{tabular}

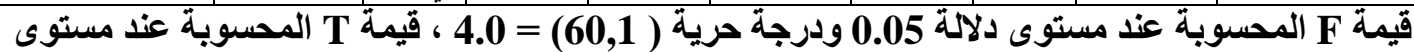
دلالة 0.05 ودرجة حرية (60)

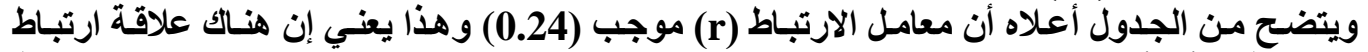

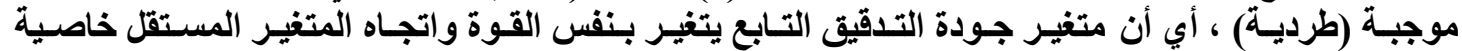

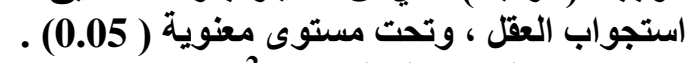

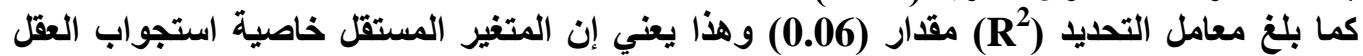

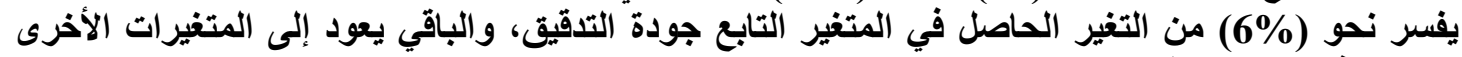
المؤثرة في جودة التدقيق.

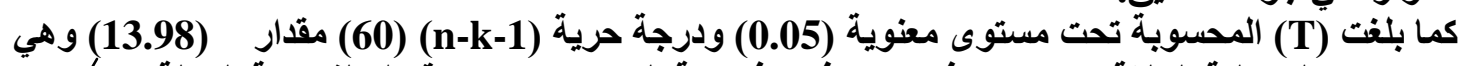

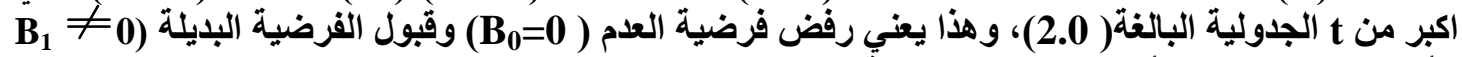

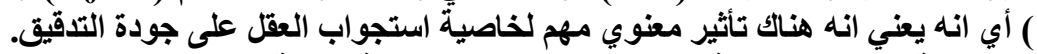

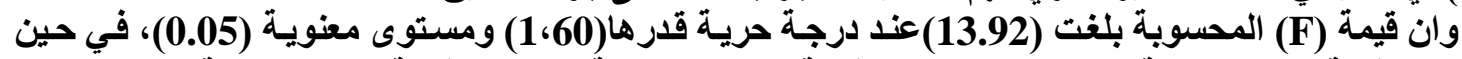

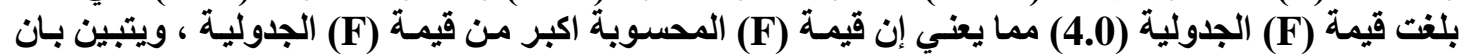

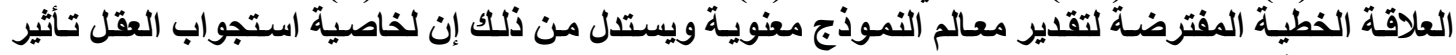
معنوي مهم في جودة التدقيق.

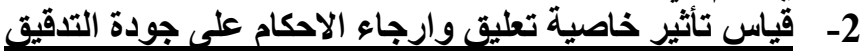

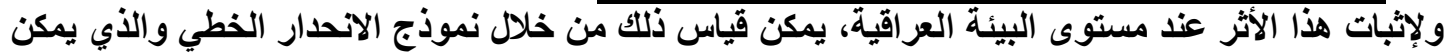
$Y_{t}=4.57+0.09 X_{2}$

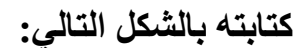

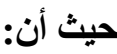

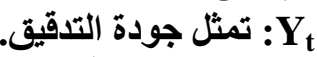
X

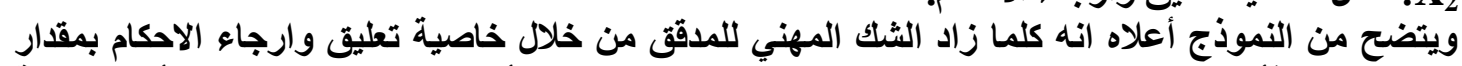

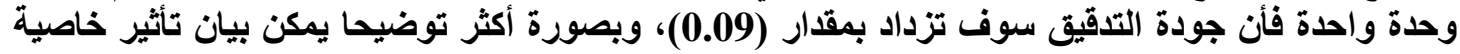
تعليق وارجاء الاحكام على جودة التدقيق، من خلال الجدول الآتي:

\begin{tabular}{|c|c|c|c|c|c|c|c|c|c|}
\hline قالفرضل (رفضة) & الثحسو & الالالة & 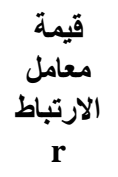 & الدلالة & قالمحسوب & 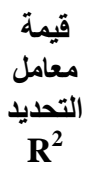 & قيمة & المتثمير & المتغير المستقل X \\
\hline العدام وقبولة البرضية & 8.70 & معنو & 0.09 & العلاقة & 9.44 & 0.007 & 4.57 & التوديق & خاصية تعليق وارجاء \\
\hline
\end{tabular}

قيمة F المحسوية عند مستوى دلالة 0.05 ودرجة حرية ( 60,1) = 4.0 ، قيمة T المحسوبة عند مستوى

$$
\text { دلالة } 0.05 \text { ودرجة حرية (60) }
$$




\section{تأثير خمائس الشلك المهني للمدقق علمى جودة التدقيقا}

ويتضح من الجدول أعلاه أن معامل الارتباط (r) موجب (0.09) وهذا يعني إن هناك إن علاقة ارتباط

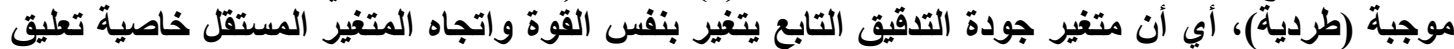

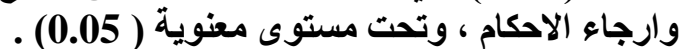

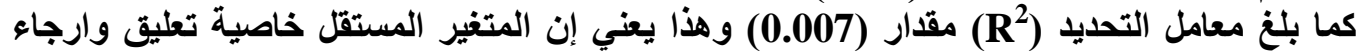

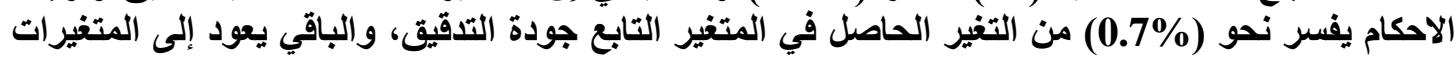

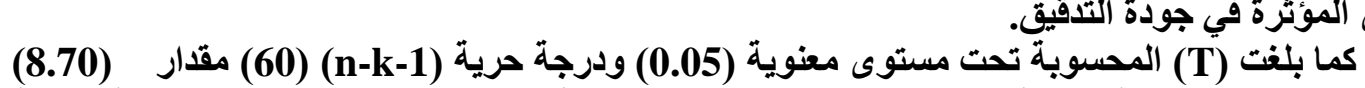

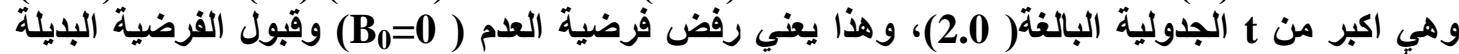

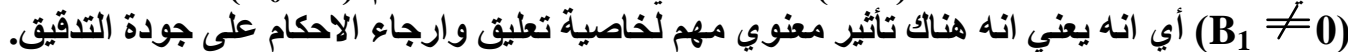

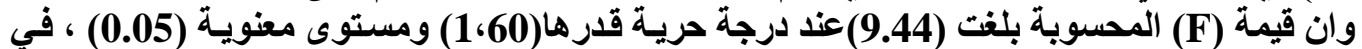

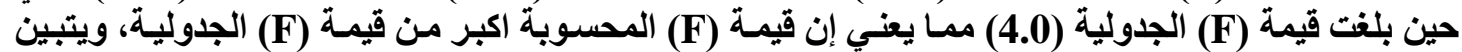

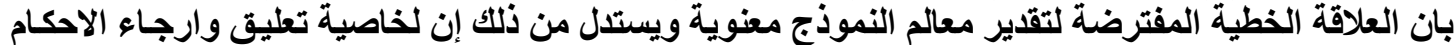

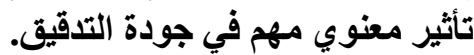

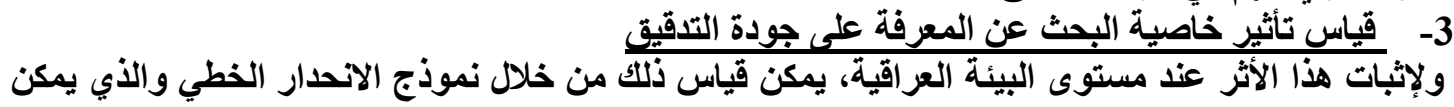
$Y_{t}=4.82+0.15 X_{3}$

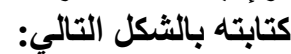

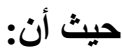

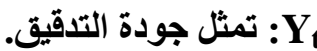
X و

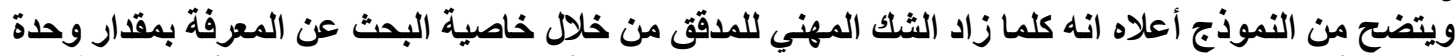

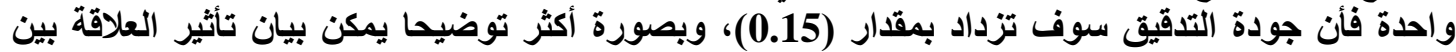

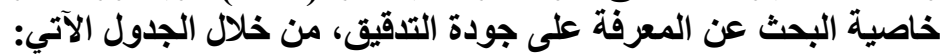
جدول (4) تأثير خاصية البحث عن المعرفئة على على جودة الآثي:

\begin{tabular}{|c|c|c|c|c|c|c|c|c|c|}
\hline قالفبوضية (رفض) & قالمحسوبة & الدلالة & 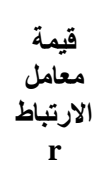 & اللالادة & قلميموبة & 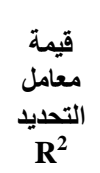 & قيمة & 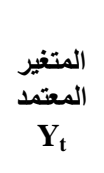 & المتغير المستقل X \\
\hline العذم وقبول فرضية & 14.18 & معنوي & 0.15 & معنوية & 11.45 & 0.02 & 4.82 & جودةد & المعرفية البحث عن \\
\hline
\end{tabular}

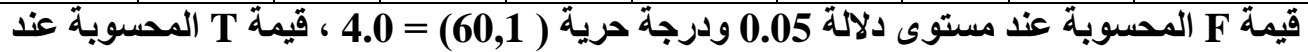

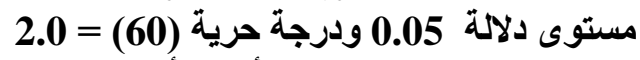

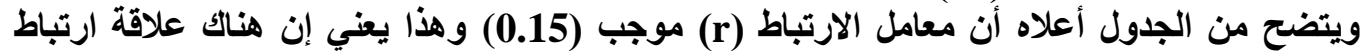

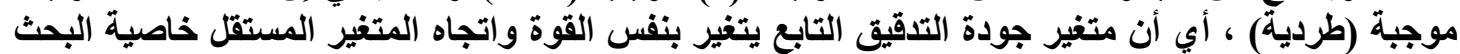

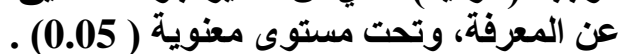

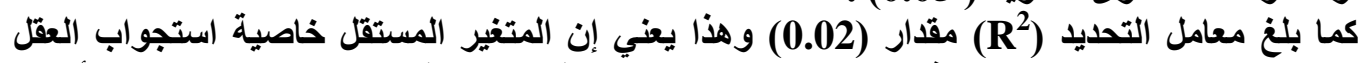

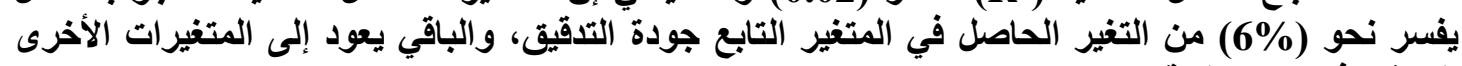

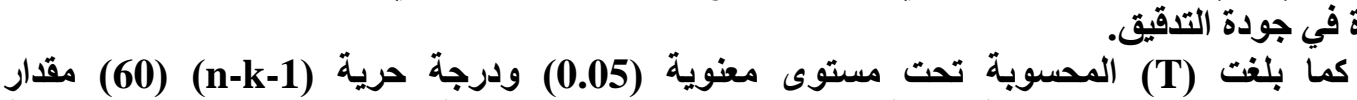

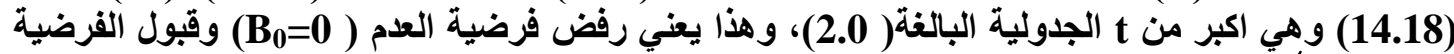
البليلة ( 0 (B) 


\section{تأثير خمائس الشلك المهني للمدقق علمى جودة التدقيقا}

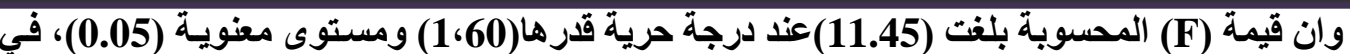

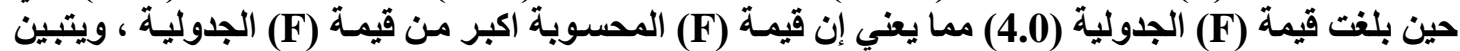

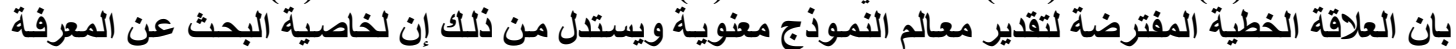
تأثير معنوي مهم في جودة التهية التدقيق.

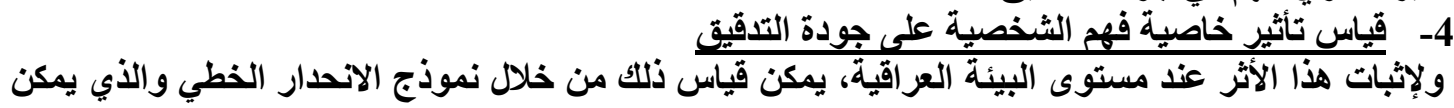
$Y_{t}=4.23+0.01 X_{4}$ كتابته بالشكل الآبات هذل الآلي:

X و

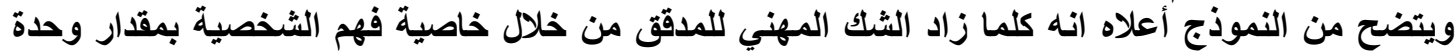

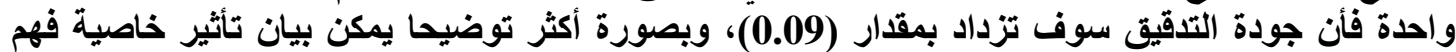
الثخصية على جودة التدقيق، من خلال الجدول الآتي: جدول (5) تأثير خاصية فهم الشخصية على جودة التدقيق

\begin{tabular}{|c|c|c|c|c|c|c|c|c|c|}
\hline قفبول (رفضة) & قيمة T المسوبة & الدالة & $\begin{array}{c}\text { قلامتلة } \\
\text { معامل } \\
\text { r }\end{array}$ & الدالة & قيمة المحسوبة & 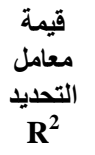 & قيمة & $\begin{array}{c}\text { المتتمدير } \\
\text { Y } \\
\text { Y }\end{array}$ & المتغير المستقل X \\
\hline العلدم وقبولية الفرضية & 8.70 & معنوي & 0.09 & العلاقة & 9.44 & 0.007 & 4.57 & جودة & خاصية استجواب العقل \\
\hline
\end{tabular}

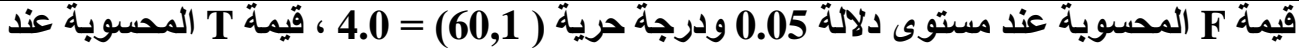

$$
\text { مستوى دلالة } 0.05 \text { ودرجة حرية (60) }
$$

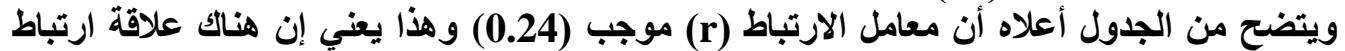

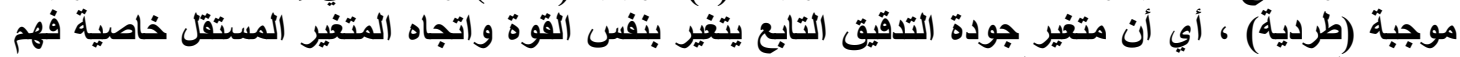

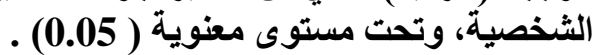

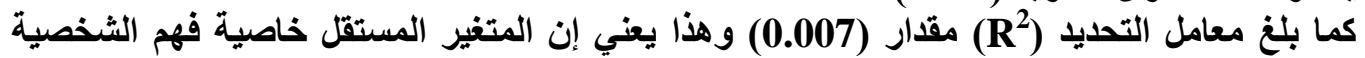
يفسر نحو (0.7\%) من التغير الحاصل في المتغير التابع جودة التدقيق، والباقي يعود إلى المتغيرات الأخرى المؤثرة في جودة التدقيق.

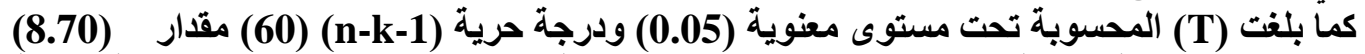

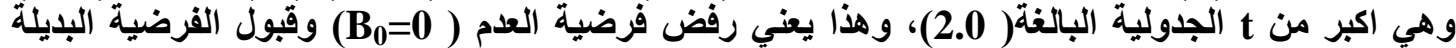

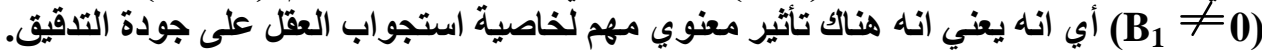

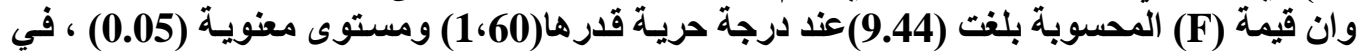

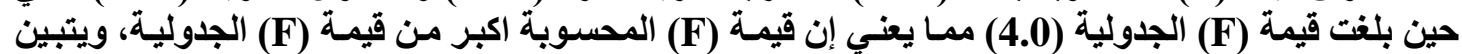

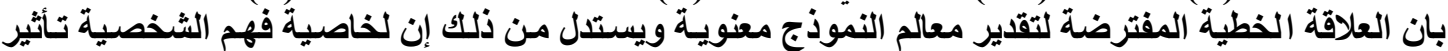
5عنوي مهم في جودة التدقيق.

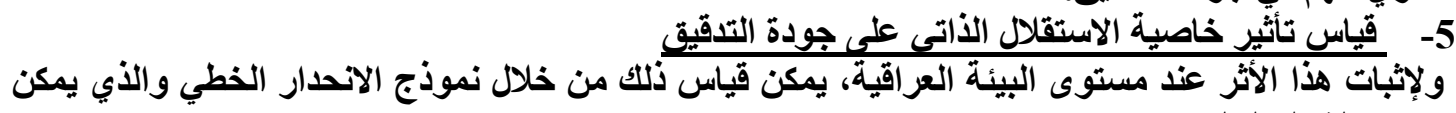
$Y_{t}=3.56+015 X_{5}$

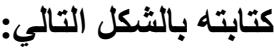

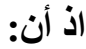

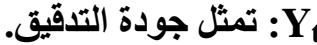

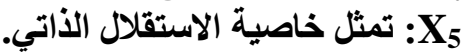


ويتضح من النموذج أعلاه انه كلما زاد الثكك المهني للمدقق من خلال خاصية الاستقلال الذاتي بمقار بـار

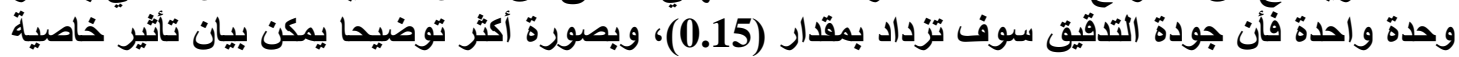

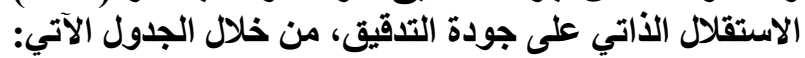

\begin{tabular}{|c|c|c|c|c|c|c|c|c|c|}
\hline قفبولية (رفض) & قيمة T المحسبة & الدلالة - مالة & $\begin{array}{c}\text { معامل } \\
\text { معيمة } \\
\text { r }\end{array}$ & الدلالة & قلقيمة F & 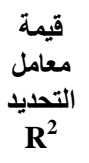 & قيمة & المتثمد & المتغير المستقل X \\
\hline العضضم وقبولية & 7.09 & ارتباط & 0.14 & معغوية & 16.23 & 0.02 & 3.56 & التدويق & خاصية الاستقلال الذاتي \\
\hline
\end{tabular}

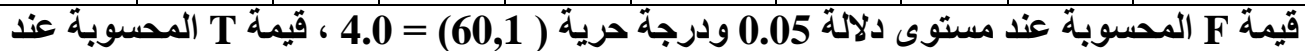

$$
\text { مستوى دلالة } 0.05 \text { ودرجة حرية (60) }
$$

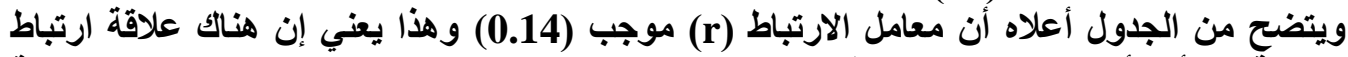

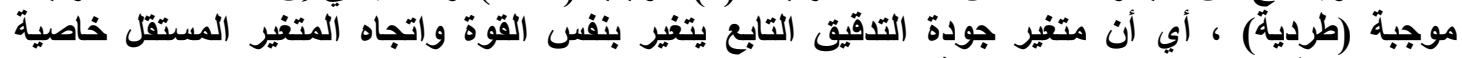

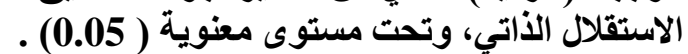

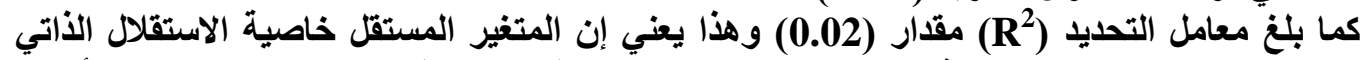

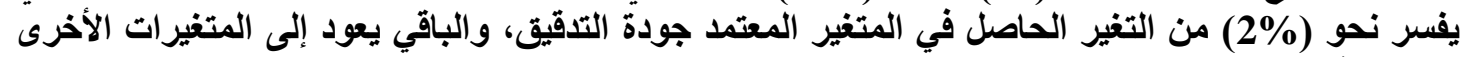
المؤثرة في جودة التدقيق.

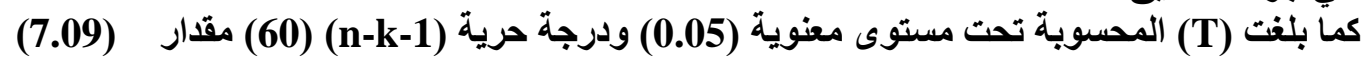

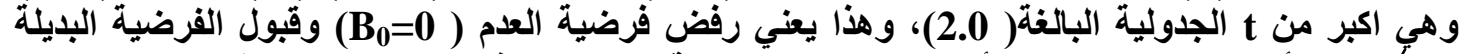

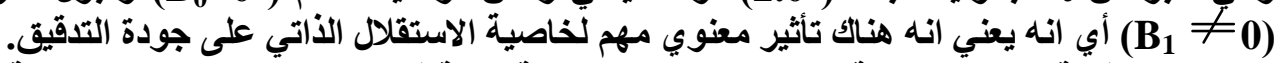

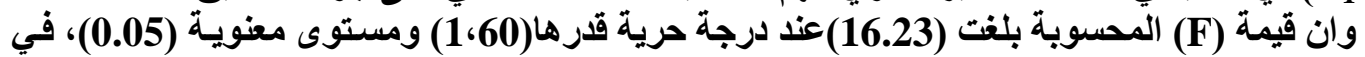

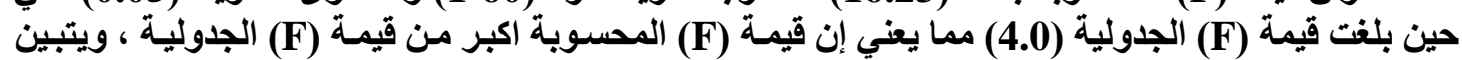

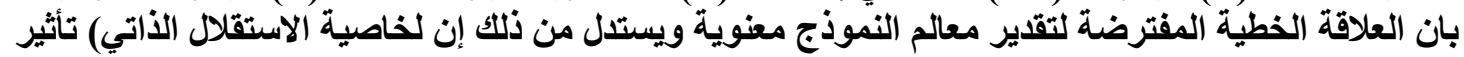
6عنوي مهم في جودة التدقيق.

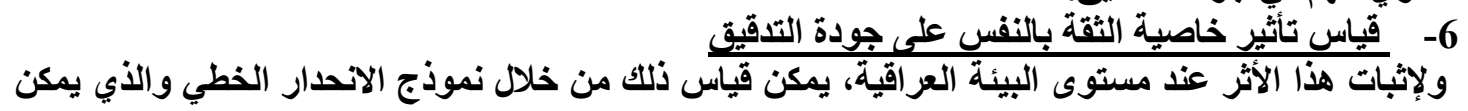
$Y_{t}=3.84+0.08 X_{6}$

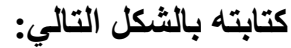

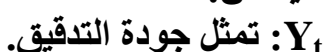
X

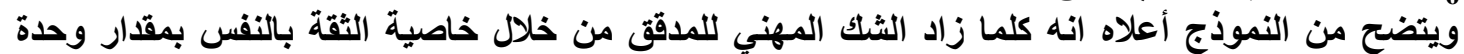

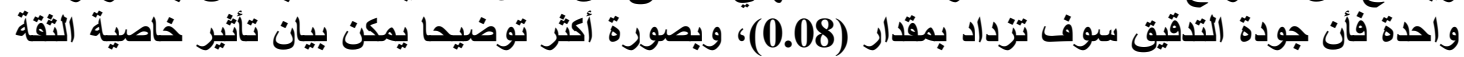

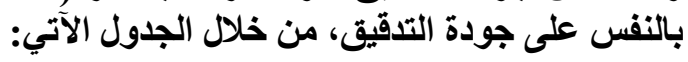




\section{تأثير خصائس الشله المهني للمدقق علىـ جودة التدقيق}

\begin{tabular}{|c|c|c|c|c|c|c|c|c|c|}
\hline قالفرضل (رفضة) & قيمة T T & الدلالة & 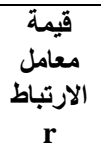 & الدلالة & قلمسمة F & 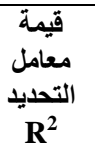 & قيمة & $\begin{array}{c}\text { المعتمد } \\
\text { Y } \\
\text { Y }_{t}\end{array}$ & المتغير المستقل X \\
\hline القدم وقبولية فرضية & 15.62 & معنوي & 0.08 & العنواقة & 15.45 & 0.007 & 3.84 & جودة & خاصية الثقة بالنفس \\
\hline
\end{tabular}

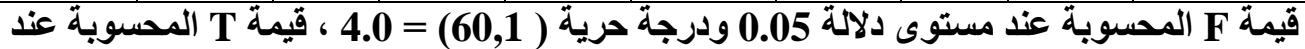

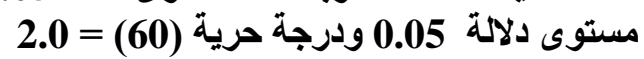

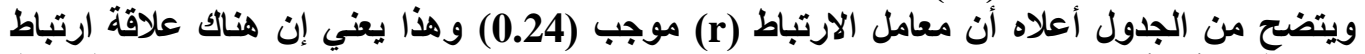

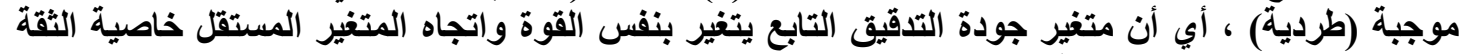

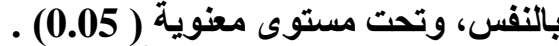

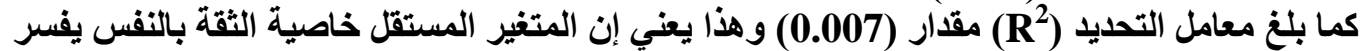

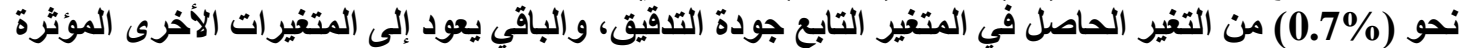

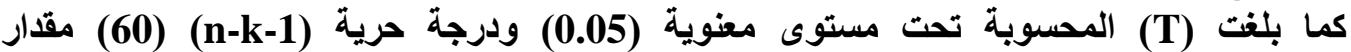
في جودة التدقيق.

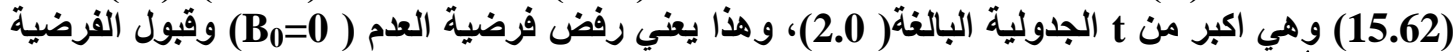

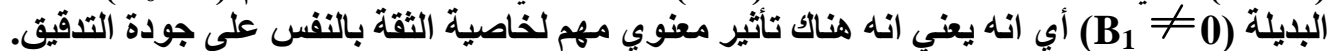

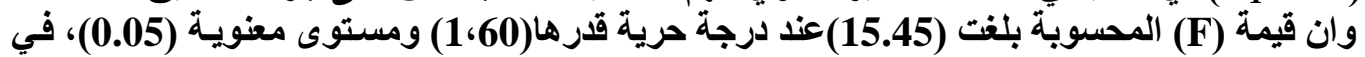

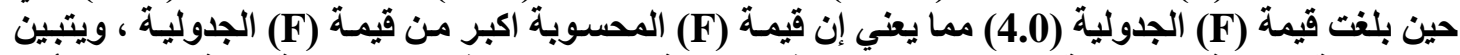

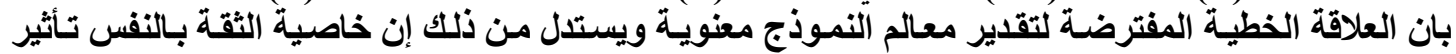
معنوي مهم في جودة التدقيق.

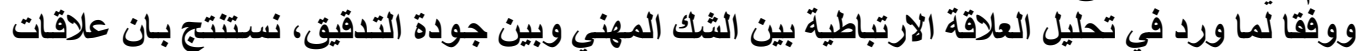

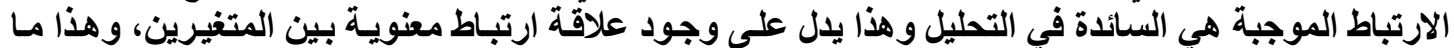

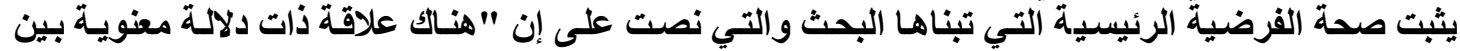

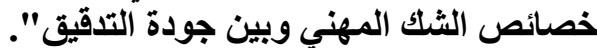

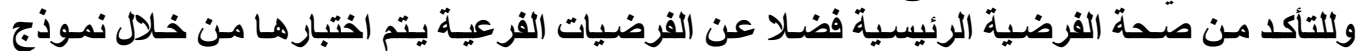
$Y_{t}=3.62+0.15 X$ الانحدار الخطي والذي يمكن كتابته بالثكل التالي:

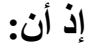

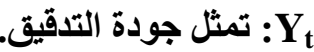

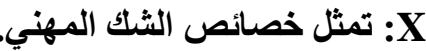

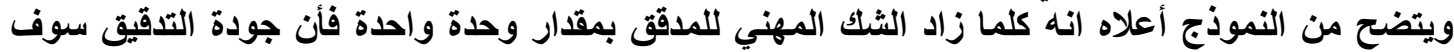

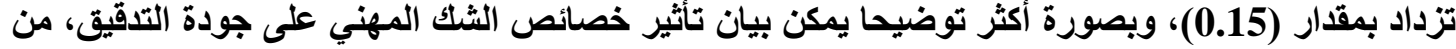

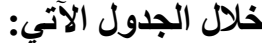
جدول (8) تأثير خصائص الثكك المهني على جودة التدقيق

\begin{tabular}{|c|c|c|c|c|c|c|c|c|c|}
\hline قاقفبوضية (رفض) & قالنحسوبة T & 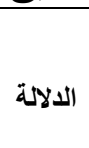 & 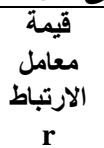 & الدلالة & المحسوبة & معاملة & قيمة & $\begin{array}{l}\text { المتثمد } \\
\text { Y } \\
\text { Y }\end{array}$ & المتغير المستقل X \\
\hline العلدم وقبولية فرضية & 11.54 & معنوي & 0.07 & العغلاقة & 6.29 & 0.005 & 3.62 & التدويقة & خصائص الثكك المهني \\
\hline
\end{tabular}

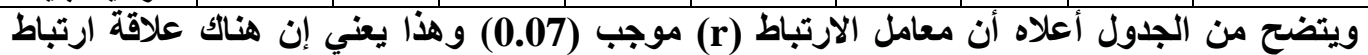

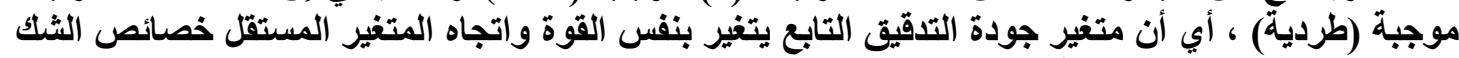

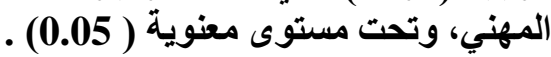




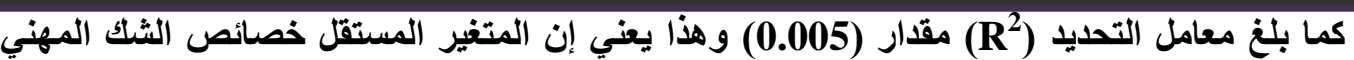

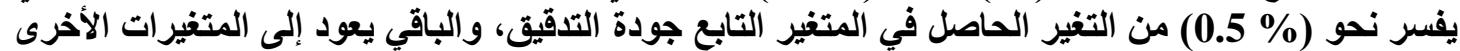

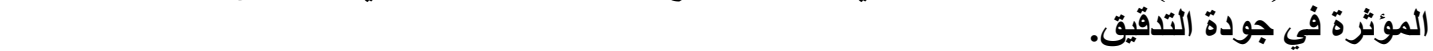

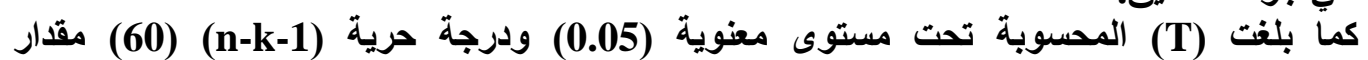

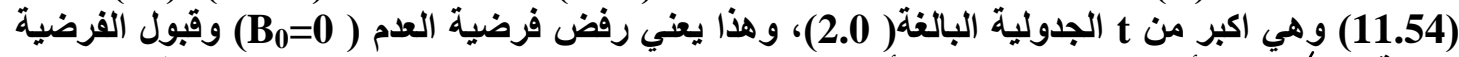
البديلة (1)

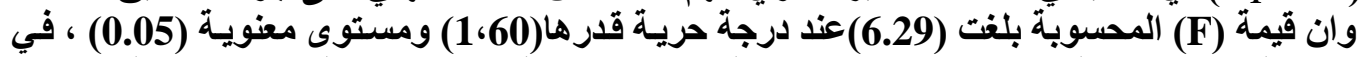

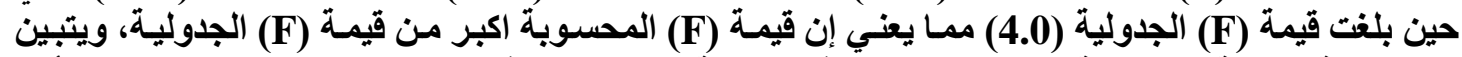
بان العلاقة الخطية المفترضة لتقلير معالم النموذج معنوية ويستدل من ذلكت إن لخصائص الثنك المهني تأثير

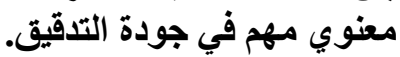

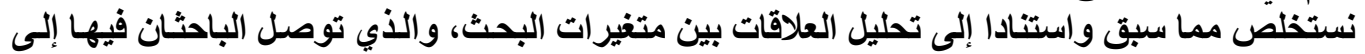

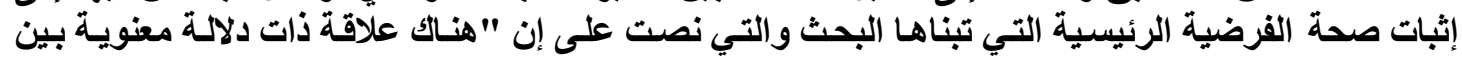

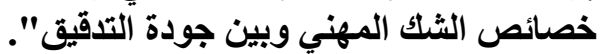

\section{المهور الرابع/ الاستنتاجات والتوصيات}

\section{الالا: الاستنتاجات}

يهدف هذا المحور إلى عرض خلاصة الداراسة النظرية وما تناوله الباحثّن، فضلاً عن الاستتتاجات التي توصل إليها البحث في الجانب التطبيقي وكالآتي:

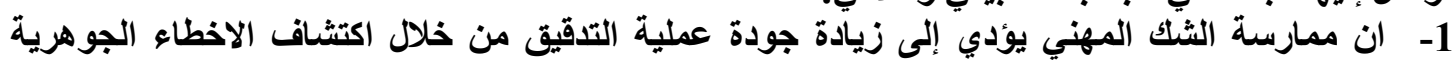

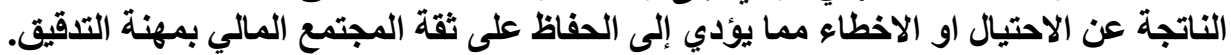

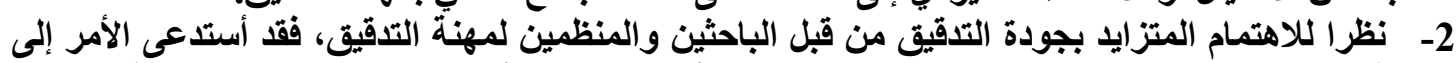

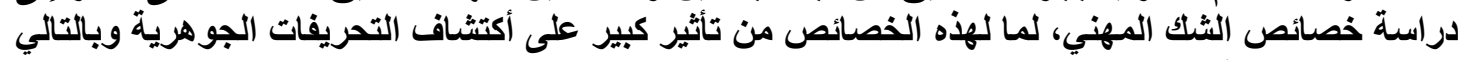
تحسين جودة التدقيق. 3- امتلاك المدققين في شركات ومكاتب التدقيق العراقية خصائص الثثك المهني بلرجة كبيرة، اذ تم من خلال استخدام الاساليب الاحصائية التوصل فئل إلى الاتي:

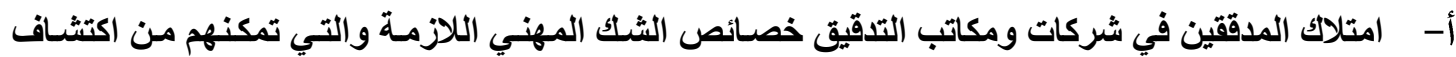
الانحر افات او الاخطاء الجوهرية.

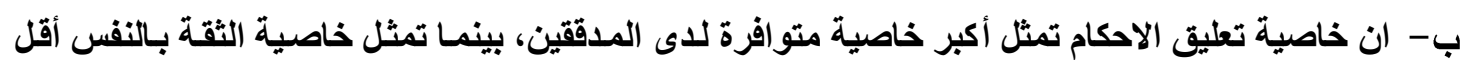
خاصية متو افرة لاى المدققين عينة البحث. ت- - اظهرت النتائج وجود تأثير لخصائص الثكك المهني للمدقق على جودة التدقيق في شركات ومكاتب

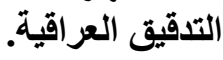

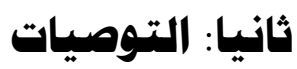
في ضوء الاستنتاجات التي توصل اليها البحث بجانبيه النظري والتطبيقي، يمكن تقيم مجموعة من التوصيات

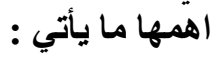
1- ضرورة قيام الهيئات التثريعية والتظظيمية في العراق والمتمثلة بمجلس مهنة مراقبة وتدقيق الحسابات

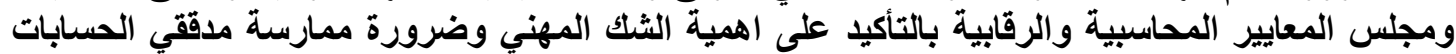
للثشك المهني اثثاء تنفيذ عملية التدقيق.

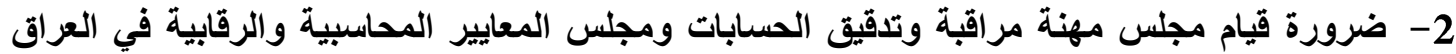

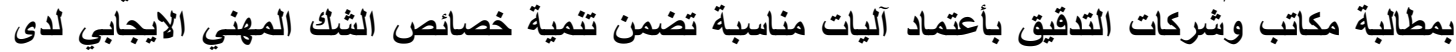
المدققين وتضمن تقليل معوقات ممارسة الثثك المهني. 
3- ضرورة قيام مكاتب وشركات التدقيق العراقية بتقييم دوري لمدى توفر خصائص الثـك المهني الايجابي

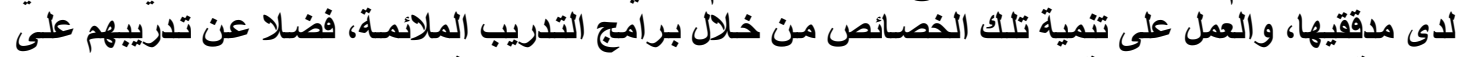

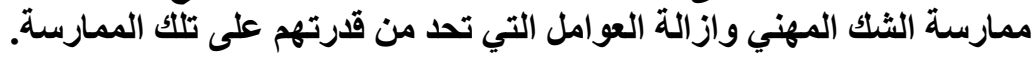

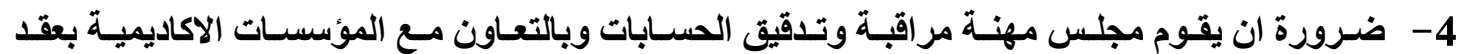

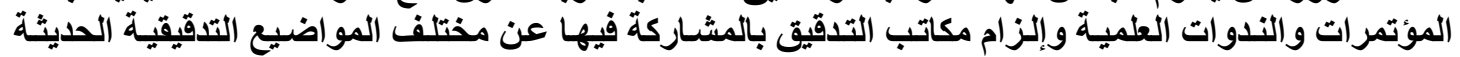
وذلك لزيادة خبرة المكتب علميا وعمليا وبالتالي تحسين جودة التبدئ التدقيق.

المادر

المسادر العربية

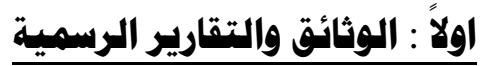

1- دليل استرشادي لوحدات التدقيق الداخلي في الوزارات، ديوان الراتية الرقابة المالية، 2011.

ثانيا : الدراسات والرسائل والاطاريج الجامعيدة:

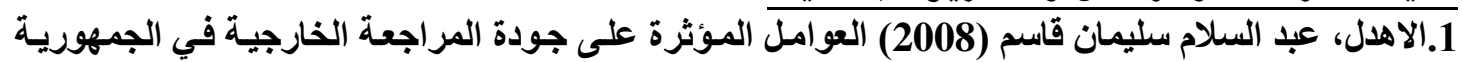

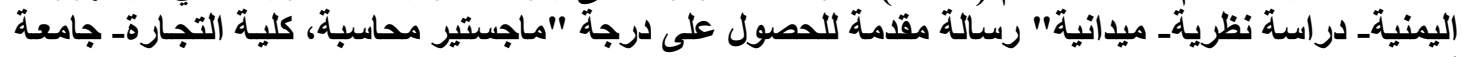

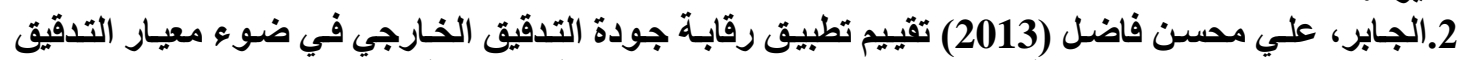

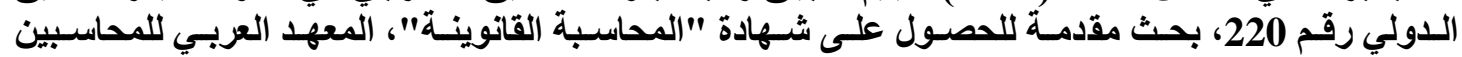
القانونيين

3.حسن، عماد عبد الرضا (2015) أثر النظام المحاسبي الموحد للبلديات على جودة المعلومسات المحاسبية في

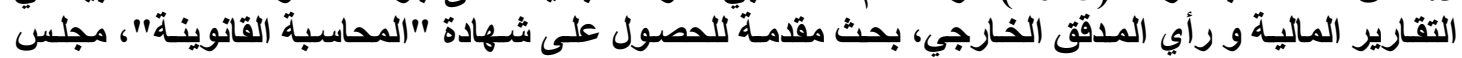

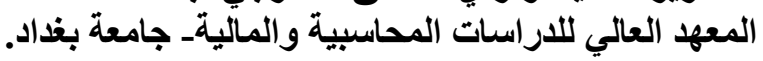

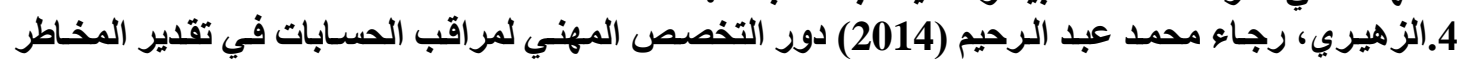

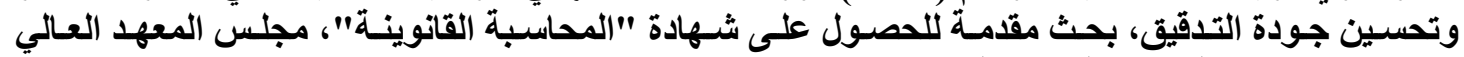

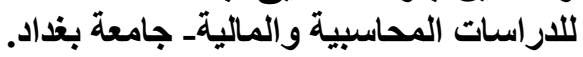

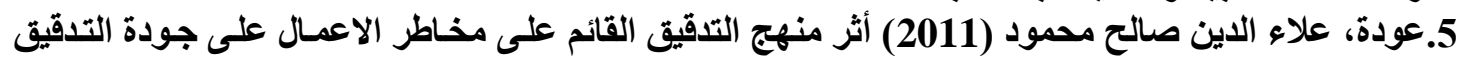

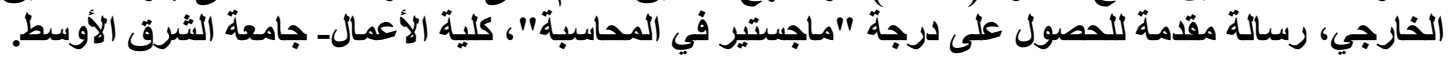

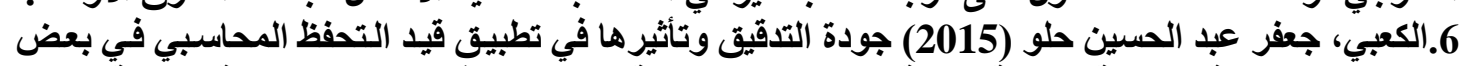

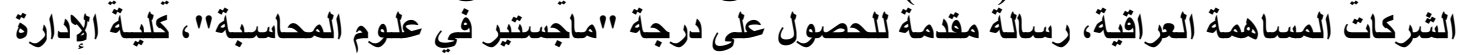

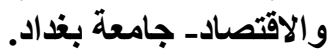

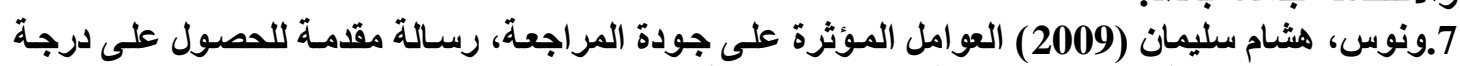

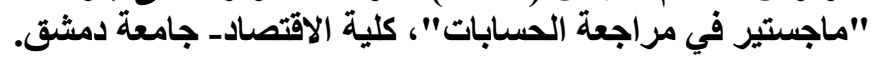

\section{ثالثا: البحرث المنشورة في في الدمه الدوريات:}

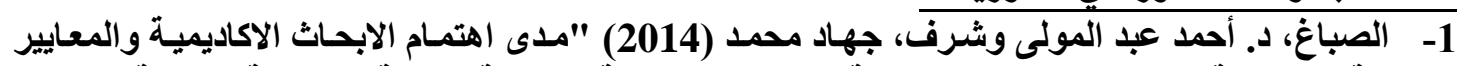

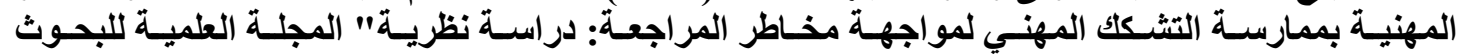

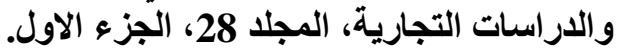

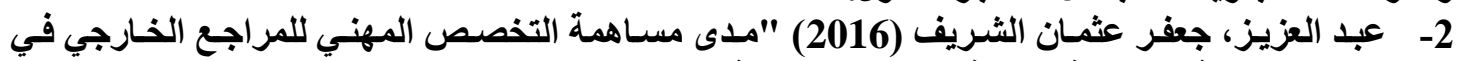
تحسين جودة عملية المراجعة" مجلة العلوم الاقتصادية، المجلد 17، العددان. 


\section{The Books}

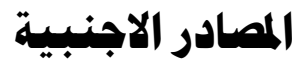

1- IAASB, International auditing and assurance standards board (2013) A Framework for audit quality, IFAC, New York.

2- IFAC, International federation of accountants (2010) Handbook of international quality control, auditing, review, other assurance, and related services pronouncements, 545th Avenue, New York-USA

\section{Publications}

1- AASB, Auditing and assurance standards board (2013) Practical ways to improve the exercise and documentation of professional skepticism in an ISA audit, Institute chartered accountants Australia.

Thesis

1- Grenier, Jonathan Hallberg (2010) Encouraging professional skepticism in the industry specialization ERA: A dual- process model and an experimental test, Thesis submitted to gain the degree of "Doctor of philosophy in accountancy in the graduate collage", University of Illinois.

2- Rasso, Jason Tyler (2013) Psychological distance: the relation between construal's, mindset and professional skepticism, Thesis submitted to gain the degree of "Doctor of philosophy", University of south Florida.

(Periodicals)

1- Al-Khaddash, Husam, Al Nawas, Rana and Ramadan, Abdulhadi (2013) "Factors affecting the quality of Auditing: The Case of Jordanian Commercial Banks'' International Journal of Business and Social Science, Vol. 4. No.11.

2- Almomani, Dr. Mohammad Abdallah (2015) The Impact of Audit Quality Features on Enhancing Earnings Quality: The Evidence of Listed Manufacturing Firms at Amman Stock Exchange, Jadara University, Asian Journal of Finance and Accounting, Vol. 7, No. 2.

3- Anis, Ahmed (2014) Auditors' Perceptions of Audit Firm Rotation Impact on Audit Quality in Egypt, Accounting\& Taxation, Vol.6, No.1.

4- Basel Committee on Banking Supervision (2013) External audits of Banks, Consultative Document, Banks for international settlements.

5- Bowlin, Kendall O., Hobson, Jessen L. and Piercey (2012) "The Effects of Auditor Rotation, Professional Skepticism and Interactions with Managers on Audit Quality"' The accounting review, Retrieved July 2015, Vol. 90, No. 4.

6- DeAngelo, Linda Elizabeth (1981) Auditor size and audit quality, Journal of accounting and economics Vol.3, No. 2, PP 183-197.

7- Enofe, DR. A. O, Ukpebor, Innocent and Ogbomo, N. (2015) "The effect of accounting ethics in improving auditor professional skepticism" International journal of advanced academic research, Vol. 1, No.2. 
8- Hamdan, Allam Mohammed Mousa, Kukrija, Gagan, Awwad, Bahaa Sobhi Abdelatif and Dergham, Maher Mousa (2012) "The auditing quality and accounting conservatism" International Management Review, Vol.8, No.2.

9- Holderness Jr., D. Kip (2014) "Detecting deception in client inquiries: A review and implications for future research" Journal of forensic\& investigative accounting, Vol.6, No. 2.

10- Hussin, Sayed Alwee Hussnie Sayed and Iskandar, Takiah Mohd. (2015) "Re-Validation of professional skepticism traits" Science Direct 28.

11- Jaya, Tresno Eka, Irene and Choirul (2016) "Skepticism, time limitation of audit, ethics of professional accountant and audit quality 9 case study in Jakarta, Indonesia)" Review of integrative business\& economics research, Vol.5(3).

12- Koeswayo, Poppy Sofia (2016) 'Effect of competence, on internal audit professionals skepticism, implications on regional head of corruption practices (case study district / city in west java province)" European journal of accounting, auditing and finance research, Vol.4, No.5, PP.90-109.

13- Kopp, Lori, Lemon W. Morley and Rennie, Morina (2003) "A Model of trust and professional skepticism in the auditor- client relationship" School of accountancy seminar series, University of waterloo.

14- Nelson, Mark W. (2009) "A Model and literature review of professional skepticism in auditing"' Auditing: a journal of practice\& theory, Vol. 28, No. 2.

15- Nolder, Christine J (2012) The role of professional skepticism, attitudes and emotions on auditor's judgment, Thesis submitted to gain the degree of "Ph.D. in Accountancy", Bentley University.

16- Quadackers, Lucas Mathias and Wijnandsrade, Geboren (2009) "A Study of auditors' skeptical characteristics and their relationship to skeptical judgments and decisions" Vrije University.

17- Ray, Thomas J. (2016) "Re: Invitation to comment: Enhancing audit quality in the public interests" International auditing and assurance standards board, New York.

18- Toba, Yoshihide (2011) "Toward a conceptual framework of professional skepticism in auditing" Wased business\& economics studies, No. 47

19- Ying, Sammy Xiaoyan (2015) "Constraints on professional skepticism in china from philosophical and historical perspectives" International journal of technical research and applications, No. 17, PP.7-15. 


\section{Effect of the professional skepticism characteristics of the auditor on audit qualit}

\section{Abstract:}

The professional skepticism is one of the fundamental concepts necessary for practicing the audit profession, without which the auditor can not reach a reasonable assurance as to the correctness of the evidence and the information obtained by the auditing department. The auditor's possession of the characteristics of professional skepticism and his practice of professional skepticism during the audit process lead to an increase The quality of audit and thus raise the confidence of the financial community in the audit profession again after the exposure of several crises led to the loss of financial society confidence in the audit profession.

The aim of the study is to measure the impact of professional skepticism on audit quality in Iraqi audit firms and offices, as well as to measure the characteristics of professional skepticism in the Iraqi audit companies and offices through a questionnaire distributed to a sample of auditors in the audit firms and audit offices in Iraq. (62) form. The effect of the variables was shown through the use of statistical models in the form of the lower squares and linear regression model. After testing the hypotheses, a set of conclusions was reached. The impact of professional skepticism on the audit quality of audit firms and audit offices in Iraq is significant. The practice of professional skepticism leads to an increase in the quality of the audit process by detecting the material errors resulting from fraud or errors, which leads to the confidence of the financial community The research recommended that the legislative and regulatory bodies in Iraq should emphasize the importance of professional skepticism and the need for auditors to exercise professional skepticism during the implementation of the audit process, which leads to increased audit quality.

Key words: professional skepticism, characteristics of professional skepticism, quality of audit.

\begin{tabular}{|c|c|}
\hline 618 & 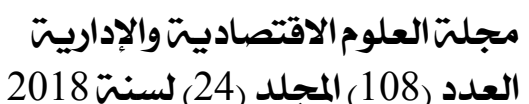 \\
\hline
\end{tabular}

